Supporting Information

\title{
Evaluation of a Peptide-Based Coassembled
}

\section{Nanofibrous and Thixotropic Hydrogel for Dermal Wound Healing}

\author{
Pramod K. Gavel,,$^{\dagger}$ Narendra Kumar,,$^{\dagger}$ Hamendra S. Parmar,,+ and Apurba K. Das ${ }^{\dagger *}$ \\ tDepartment of Chemistry, Indian Institute of Technology Indore, Indore 453552, India \\ ${ }^{*}$ School of Biotechnology, Devi Ahilya University, Indore 452001, India \\ E-mail: apurba.das@iiti.ac.in
}


Table of Contents

\begin{tabular}{|c|c|}
\hline Contents & Page No. \\
\hline Materials and methods & S3 \\
\hline Purification of $\mathbf{1}$ & S4 \\
\hline Characterizations of $\mathbf{1}$ & S4-S5 \\
\hline Antibacterial test & S5 \\
\hline Cell culture experiments & S6 \\
\hline Confocal experiments & S6 \\
\hline In vivo experiments & S6 \\
\hline Synthesis of $\mathbf{1}$ & S7-S13 \\
\hline Mass, ${ }^{1} \mathrm{H}$ and ${ }^{13} \mathrm{C}$ NMR spectra (Figure S1-S10) & S13-S18 \\
\hline HPLC chromatogram of 1 (Figure S11) & S18 \\
\hline Preparation of the hydrogels 1-5 with different concentrations of CD (Table S1) & S19 \\
\hline Rheological data of the hydrogels 2,3 and 5 (Figure S12) & S20 \\
\hline Photographs of self-recovery and injectability of hydrogel 4 (Figure S13) & S21 \\
\hline${ }^{1} \mathrm{H}$ NMR data of the CD, peptide 1 and xerogel 4 (Figure S14) & S22 \\
\hline${ }^{1} \mathrm{H}$ NMR data of the CD and xerogel 4 (Table S2) & S22 \\
\hline${ }^{1} \mathrm{H}$ NMR data of the peptide 1 and xerogel 4 (Table S3) & S23 \\
\hline FTIR spectra of the CD, peptide 1 and xerogel 4 (Figure S15) & S23 \\
\hline The concentration-dependent UV-vis spectra of hydrogels 1 and $\mathbf{4}$ (Figure S16) & S24 \\
\hline The antibacterial data of hydrogel 4 against Gram-positive bacteria (Figure S17) & S24 \\
\hline The antibacterial data of hydrogel 4 against Gram-negative bacteria (Figure S18) & S25 \\
\hline Confocal microscopy images of A431 cells (Figure S19) & S25 \\
\hline Total protein estimation data (Figure S20) & S26 \\
\hline Statistical Analyses & S26 \\
\hline
\end{tabular}




\section{Materials and Methods}

All the materials used for this project were procured from commercial sources and used as received. The 9-anthracenemethanol, 4-nitrophenyl chloroformate and pyridine were purchased from Sigma-Aldrich (Merck KGaA), India. L-Phenylalaninne (F), dicyclohexylcarbodiimide (DCC) and 1-hydroxybenzotriazole (HOBt) were purchased from SRL, India. The $\beta$-cyclodextrin (CD) hydrated was procured from Alfa Aesar, India. The chemicals for biological experiments i.e. peptone powder, yeast extract, agar agar powder, Dulbecco's Modified Eagle Medium (DMEM), Minimum Essential Medium Eagle (MEM), Trypsin-EDTA solution 1X, PenicillinStreptomycin antibiotic solution 100X and 3-(4,5-dimethythiazol-2-yl)2,5-diphenyl tetrazolium bromide (MTT) powder were purchased from HiMedia Laboratories Pvt. Ltd., India. The silverex gel (silver nitrate $0.2 \%$ w/w, Sun Pharma, India), povidone-iodine (Win Medicare Pvt. Ltd., India), Dynapar AQ (Diclofenac $75 \mathrm{mg} / \mathrm{mL}$ injection) Tegaderm (3M bandage), hair removal cream Anne French (Pfizer, India), and the disposable biopsy punch ( $8 \mathrm{~mm}$, amazon, India) were purchased commercially for the research purposes. All solvents were analytical grade and purchased from Rankem, India; and Merck, India. HPLC grade acetonitrile (ACN) and methanol $(\mathrm{MeOH})$ were used for the analysis of the synthesized molecules. Solvents were distilled prior to use and kept in $4 \AA$ molecular sieves. Tetrahydrofuran (THF), $N, N^{\prime}$ 'dimethylformamide (DMF), ethyl acetate (EtOAc), $\mathrm{MeOH}$, hexane were dried using the standard procedure. Thin-layer chromatography was performed on pre-coated silica gel plates (Kieselgel $60 \mathrm{~F}_{254}$, Merck). Synergy $\mathrm{H} 1$ multimode microplate reader was used for 96-well microplates reading at $25^{\circ} \mathrm{C}$. 


\section{Purification of the Peptide}

Peptide and their intermediates were purified by Flash Chromatography (TELEDYNE ISCO, USA; model: CombiFlash®Rf+) using silica gel (200 mesh size) with EtOAc/hexane (ratio as required) as eluent. The purified peptides were recrystallized in THF by slow evaporation methods to get crystalline peptides and used for further experiments.

\section{Characterizations}

\subsection{Spectroscopic and High-Performance Liquid Chromatography (HPLC) Experiments}

The nuclear magnetic resonance spectroscopy (NMR) experiments were performed in $\mathrm{CDCl}_{3}$ and DMSO- $\mathrm{d}_{6}$ on a Bruker AV $400 \mathrm{MHz}$ spectrometer. The peptide concentrations used for the ${ }^{1} \mathrm{H}$ and ${ }^{13} \mathrm{C}$ NMR were $2-5$ and $120-130 \mathrm{mmol} \mathrm{L}^{-1}$ respectively. The chemical shifts $(\delta)$ are reported in ppm, downfield of tetramethylsilane (TMS). Peak multiplicities are reported as follows: singlet (s), doublet (d), triplet (t), quartet (q) and multiplet (m) and broad (b). The electrospray ionization mass spectrometry (ESI-MS) was acquired on a Bruker micrOTOF-Q II mass spectrometer by a positive-mode electrospray ionization process. HPLC analysis was carried out using a Dionex HPLC-Ultimate 3000 pump. A Dionex Acclaim ${ }^{\mathrm{TM}} 120 \mathrm{C} 18$ column of $250 \mathrm{~mm}$ length with an internal diameter $4.6 \mathrm{~mm}$ and $5 \mu \mathrm{m}$ fused silica particles at a flow rate of $1 \mathrm{~mL}$ $\min ^{-1}$ coupled with UV-Vis detector. UV-vis spectroscopy was performed on JASCO V-750 spectrometer. The concentration-dependent UV-vis experiments were performed using diluted hydrogels $\left(500,250,125,62.5,31.25,15.62,7.81,3.90 \mu \mathrm{mol} \mathrm{L}^{-1}\right)$. The circular dichroism spectra were recorded at $25{ }^{\circ} \mathrm{C}$ using a JASCO J-815 spectropolarimeter. The concentrationdependent circular dichroism experiments were performed using diluted hydrogels $(20,8,4,2,1$, $0.5,0.25 \mathrm{mmol} \mathrm{L}^{-1}$ ). The FTIR spectroscopy was performed on $\mathrm{KBr}$ pellets on a Bruker Tensor 27 FTIR spectrophotometer. The hydrogel was placed between crystal $\mathrm{Zn}-\mathrm{Se}$ windows for FTIR analysis and scanned between $600-4000 \mathrm{~cm}^{-1}$. The powder X-ray diffraction spectroscopy (PXRD) was performed in the $2 \theta$ range of $6^{\circ} \sim 60^{\circ}$ using a Bruker D2 Phaser X-ray diffractometer with a $\mathrm{Cu}-\mathrm{K} \alpha$ radiation source $(\lambda=1.5414 \AA)$. Confocal laser scanning microscope (CLSM) was performed using an inverted microscope (Olympus, model no. FV1200MPE, IX-83). 


\subsection{Electron Microscopy Experiments}

The high-resolution transmission electron microscopy (HRTEM) images were captured using a FEI electron microscope (model: Tecnai G2, F30), operated at an accelerating potential of 300 $\mathrm{kV}$ (Magnification, 58X to $\left.1 \times 10^{6} \mathrm{X}\right)$. The images were captured using $2 \%(\mathrm{w} / \mathrm{v})$ phosphotungstic acid as a negative stain. The dilute solution $\left(2 \mathrm{mmol} \mathrm{L}^{-1}\right)$ of the hydrogel was used for the HRTEM experiment.

\subsection{Rheological Experiments}

Rheological experiments were performed at $25{ }^{\circ} \mathrm{C}$ on an Anton Paar Physica MCR 301 rheometer. The amplitude sweep experiment was performed at constant frequency of $10 \mathrm{rad} \mathrm{s}^{-1}$ and region of deformation was evaluated. The hydrogels 1-5 were placed in between of a stainless steel parallel-plate (diameter: $25 \mathrm{~mm})$ with TruGap $(0.5 \mathrm{~mm})$. The frequency sweep experiment was performed in the range of 0.05-100 $\mathrm{rad} \mathrm{s}^{-1}$ with the same strain percent found by amplitude sweep experiment. The step strain experiment was performed by varying low-highlow strain at constant frequency of $10 \mathrm{rad} \mathrm{s}^{-1}$.

\section{Antibacterial Test}

\subsection{Inoculum Growth}

The nutrient agar (NA) plate method was used to evaluate the antibacterial activity of the hydrogels. The bacterial culture Staphylococcus aureus (S. aureus, MTCC 87), Bacillus subtilis (B. subtilis, MTCC 441) and Escherichia coli (E. coli, MTCC 484) bacteria were procured from the Institute of Microbial Technology Chandigarh (CSIR-IMTech), India. Fresh inoculum was grown in nutrient broth (NB) and used for the experiments. The NA was prepared by dissolving peptone $(10 \mathrm{gm})$, yeast extract $(3 \mathrm{gm}), \mathrm{NaCl}(5 \mathrm{gm})$, agar-agar powder $(20 \mathrm{gm})$ in $1000 \mathrm{~mL}$ water. The NB was prepared similarly as NA by eliminating agar-agar powder and autoclaved before use.

\subsection{Hydrogel Treatment}

The hydrogel was prepared by maintaining the aseptic conditions. The sterile Milli-Q water, 0.5 $\mathrm{M} \mathrm{NaOH}$ and $0.1 \mathrm{M} \mathrm{HCl}$ were used for the hydrogel preparation under the laminar air flow. The hydrogel $4\left(20 \mathrm{mmol} \mathrm{L}^{-1}\right)$ was treated with Gram-positive (S. aureus and B. subtilis) and Gramnegative (E. coli) bacteria. The bacterial culture was grown for $12 \mathrm{~h}$ at $37^{\circ} \mathrm{C}$ and used for the experiment. The absorbance $\left(\mathrm{OD}_{600}=0.1\right)$ of bacterial culture was set according to McFarland standard $\left(2 \times 10^{8} \mathrm{cfu} / \mathrm{mL}\right)$. A $100 \mu \mathrm{L}$ of hydrogel 4 was transferred in a sterile centrifuge tube 
and $400 \mu \mathrm{L}$ of NB was added slowly on the top of hydrogel. A $10 \mu \mathrm{L}$ of bacterial culture $\left(2 \times 10^{6}\right.$ $\mathrm{cfu} / \mathrm{mL}$ ) was added to the NB containing hydrogel 4 . The microcentrifuge tubes were incubated at $37{ }^{\circ} \mathrm{C}$ for $12 \mathrm{~h}$ for the bacterial growth. After treatment, $10 \mu \mathrm{L}$ of bacterial suspension containing hydrogel was 10-fold diluted and whole plate streaked in a sterile nutrient agar plate. The reduction in the bacterial colonies was visually observed in the nutrient agar plate.

\section{Cell Culture Experiments}

The cell culture experiments were performed in DMEM (Dulbecco's Modified Eagle Medium contains $4 \mathrm{mM}$ L-glutamine, $1000 \mathrm{mg} / \mathrm{L}$ glucose, and $110 \mathrm{mg} / \mathrm{L}$ sodium pyruvate) with $10 \% \mathrm{FBS}$ (fetal bovine serum) and $1 \%$ antibiotic (penicillin-streptomycin) solution. The hydrogels were diluted in cell culture media and used for the experiments. The resulting hydrogels

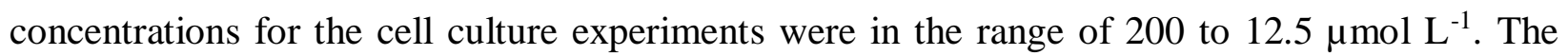
MCF-7 and HEK293 cells were used for the biocompatibility test. The hydrogels were treated with MCF-7 and HEK293 $\left(8 \times 10^{3}\right.$ cells/well) cells for $24 \mathrm{~h}$ at $37{ }^{\circ} \mathrm{C}$. After treatment, the cell culture media was removed very carefully and cells were washed with PBS $\left(10 \mathrm{mmol} \mathrm{L}^{-1}, \mathrm{pH}\right.$ 7.4) to remove the excess hydrogel. After washing, the fresh DMEM (Dulbecco's Modified Eagle Medium) was added into the 96 well plate. The cytotoxic effect was evaluated by 3-(4,5dimethylthiazol-2-yl)-2,5-diphenyltetrazolium bromide (MTT) assay. The absorbance was taken at $570 \mathrm{~nm}$ using a microplate reader (Synergy $\mathrm{H} 1$ multimode microplate reader). ${ }^{11}$

\section{Confocal Experiments}

The A431 cells were grown in sterile cover slip in DMEM for $24 \mathrm{~h}$. The different hydrogel concentrations $(50$ and $100 \mu \mathrm{M})$ were treated with the cells for the uptake of peptides $(6 \mathrm{~h}$ at 37 $\left.{ }^{\circ} \mathrm{C}\right)$. The cells were washed twice with PBS to remove the excess hydrogel. The cells were treated with thiazole orange $(50$ and $100 \mu \mathrm{M})$ for $30 \mathrm{~min}$. The excess dye was slowly removed by PBS washing. The cells were fixed in paraformaldehyde (4\% w/v) and mounted in fresh glass slide for the confocal laser scanning microscopy (CLSM). The hydrogel and thiazole orange were excited at $\lambda_{\mathrm{ex}}=405$ and $488 \mathrm{~nm}$, respectively.

\section{In vivo Experiments}

In vivo wound healing experiments were performed according to the Institutional Animal Ethical Committee (IAEC) guidelines. The experimental approval was taken prior to the wound healing experiments. Wistar albino male rats (weight $180 \pm 10 \mathrm{gm}$ ) were housed in polypropylene cages in a standard photoperiod $\left(14 \mathrm{~h}\right.$, light:10 h, dark, $\left.27 \pm 2{ }^{\circ} \mathrm{C}\right)$ with the provision of laboratory feed 
(Gold Mohur feed, Hindustan Lever Limited, Mumbai, India) and water ad libitum. Animals were maintained in accordance with the guidelines of the Committee for the Purpose of Control and Supervision of Experiments on Animals (CPCSEA), Ministry of Environment, Forest and Climate Change, New Delhi, Government of India (Reg. No. 779/Po/Ere/S/03/CPCSEA).

\section{Synthesis of Peptide}

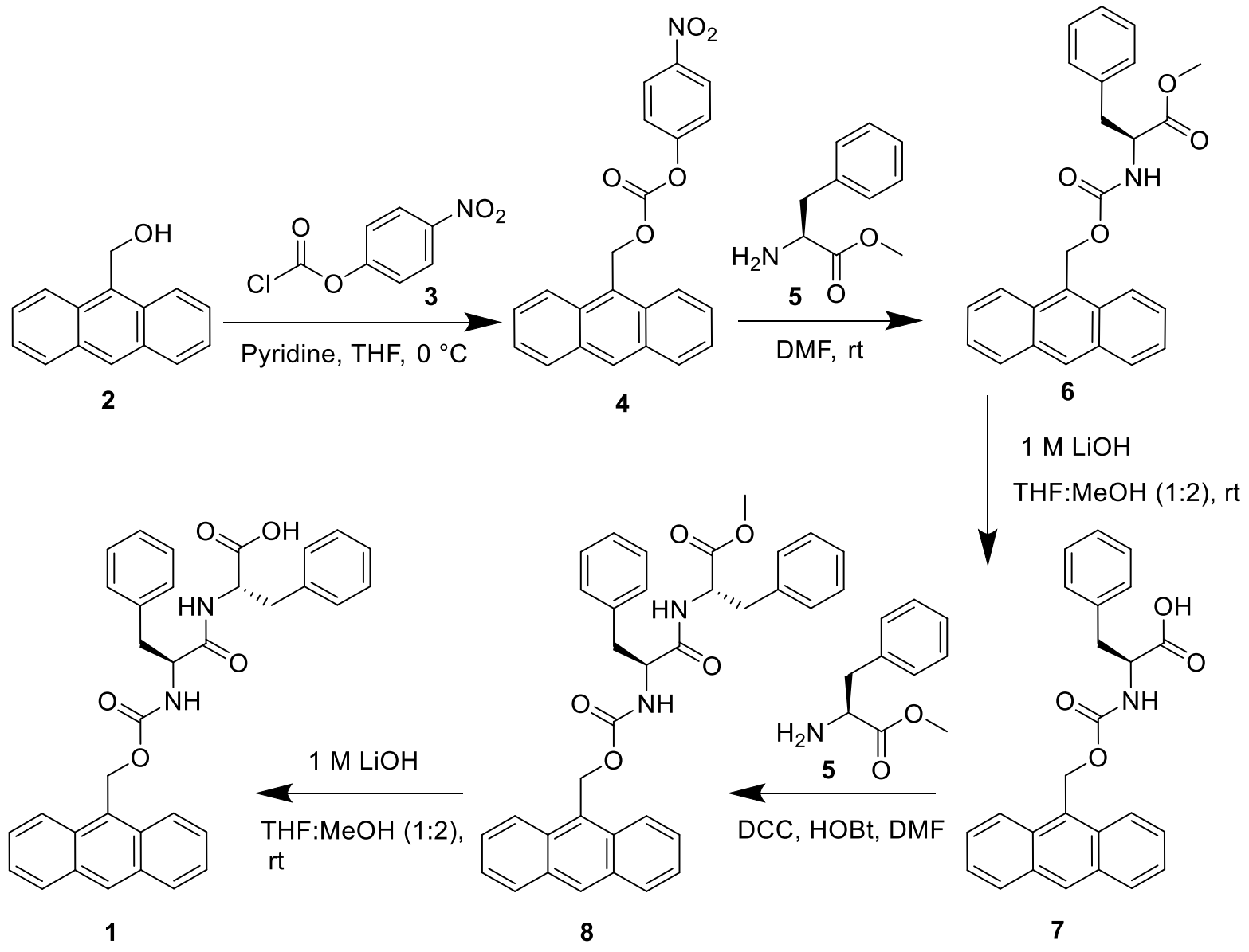

Scheme S1. Synthetic pathway of peptide 1. 


\subsection{Synthesis of 4}

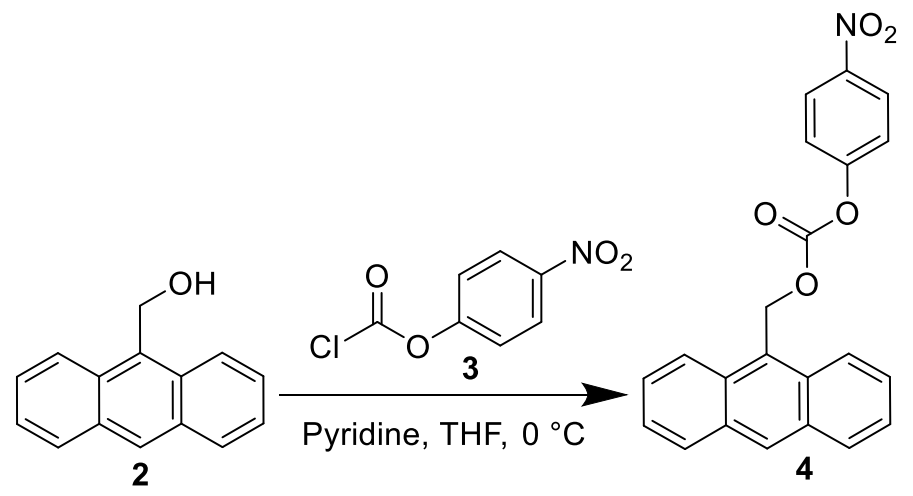

3 (1.5 g, $7.44 \mathrm{mmol}$ ) was solubilized in dry THF under $\mathrm{N}_{2}$ atmosphere. The solution was icecooled and pyridine $(0.648 \mathrm{~g}, 8.18 \mathrm{mmol})$ was added into the cold solution. The white slurry was obtained after the addition of pyridine. 2 (1.29 g, $6.2 \mathrm{mmol})$ was solubilized in dry THF and the solution was added into the reaction mixture by several portions. The reaction mixture was allowed to stir overnight at room temperature. The product conversion was checked by TLC. THF was evaporated by a rotary evaporator. The crude reaction mixture was diluted with EtOAc $(50 \mathrm{~mL})$ and the mixture was washed with $1 \mathrm{M} \mathrm{HCl}(3 \times 30 \mathrm{~mL})$. The yellow-green product was obtained by evaporating the solvent under reduced pressure. The product was recrystallized using benzene and yellow needle-shaped crystal of $\mathbf{4}$ was further used for the synthesis of $\mathbf{1}$.

Yield: $1.7 \mathrm{~g}(73 \%) .{ }^{1} \mathrm{H}$ NMR $\left(400 \mathrm{MHz}, \mathrm{CDCl}_{3}\right): \delta=8.58$ (s, $\left.1 \mathrm{H}, \mathrm{Amoc}\right), 8.42-8.40(\mathrm{~d}, J=8.88$ Hz, 2Hs, Ph), 8.26- 8.24 (d, $J=8.44 \mathrm{~Hz}, 2 \mathrm{Hs}$, Amoc), 8.08-8.06 (d, $J=8.40 \mathrm{~Hz}, 2 \mathrm{H}$, Amoc), 7.65-7.61 (t, $J=7 \mathrm{~Hz}, 2 \mathrm{H}$, Amoc), 7.55-7.51 (t, $J=7.48 \mathrm{~Hz}, 2 \mathrm{H}$, Amoc), 7.37-7.35 (d, $J=8.36$ $\mathrm{Hz}, 2 \mathrm{H}, \mathrm{Ph}), 6.39 \mathrm{ppm}(\mathrm{s}, 2 \mathrm{H}, \mathrm{Amoc}) \mathrm{ppm}$. 


\subsection{Synthesis of 6}

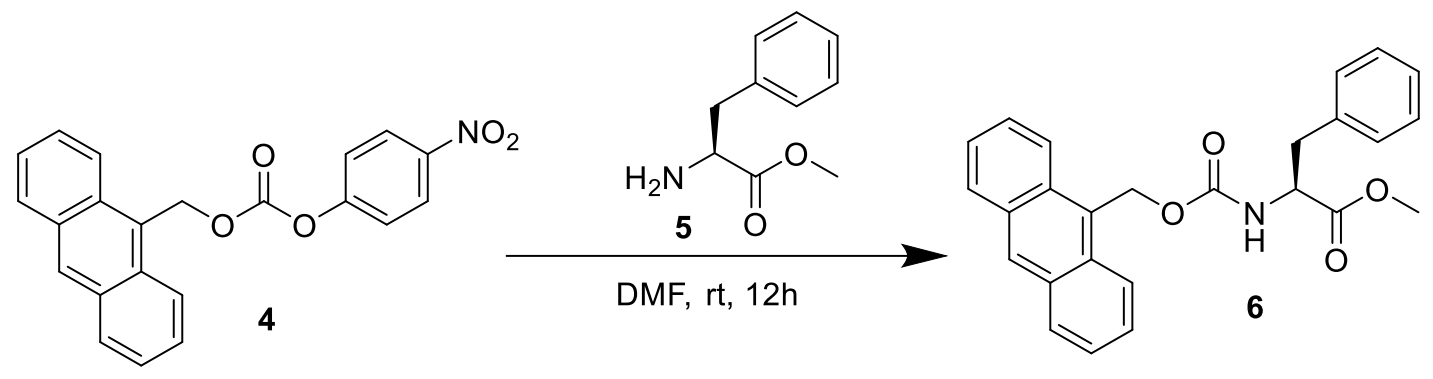

4 (1.2 g, $3.48 \mathrm{mmol})$ was dissolved in $3 \mathrm{~mL}$ dry DMF. The hydrochloride salt of 5 (1.25 g, 6.96 mmol) was neutralized using saturated $\mathrm{Na}_{2} \mathrm{CO}_{3}(10 \mathrm{~mL})$ solution and the product was extracted using EtOAc $(3 \times 30 \mathrm{~mL})$. The neutralized 5 was drop-wise added to ice-cooled reaction mixture and allowed to stir for $12 \mathrm{~h}$. The product conversion was confirmed by TLC. After completion of the reaction, EtOAc $(25 \mathrm{~mL})$ was added and washed with $1 \mathrm{M} \mathrm{HCl}(3 \times 30 \mathrm{~mL})$, saturated $\mathrm{Na}_{2} \mathrm{CO}_{3}$ solution $(6 \times 30 \mathrm{~mL})$ and then with brine. Solid yellow 6 was obtained after evaporating the solvent under reduced pressure. The product $\mathbf{6}$ was recrystallized in cold methanol.

Yield: 1.32 g (86\%); FT-IR (KBr): $\bar{v}=3302$ (s, NH), 1743 (s, COOMe), 1687 (s, amide I band), 1658 (s, amide I band), 1543 (s, amide II band) $\mathrm{cm}^{-1} ;{ }^{1} \mathrm{H}$ NMR (400 MHz, DMSO-d 6 ): $\delta=8.68$ (s, 1H, Amoc), 8.34-8.31 (d, $J=8.72 \mathrm{~Hz}, 2 \mathrm{H}$, Amoc), 8.13-8.11 (d, $J=8.24 \mathrm{~Hz}, 2 \mathrm{H}$, Amoc), 7.72-7.70 (d, J = 7.92, 1H, NH), 7.62-7.53 (m, 4H, Amoc), 7.20-7.19 (br, m, 5H, Phe), 6.075.97 (q, 2H, Amoc), 4.29-4.28 (br, m, 1H, $\mathrm{C}^{\alpha} \mathrm{H}$ of Phe), 3.61 (s, 3H, OCH 3$), 3.02-2.79$ (m, 2H, $\mathrm{C}^{\beta} \mathrm{H}$ of Phe) ppm; MS (ESI): $m / z$ calcd for $\mathrm{C}_{26} \mathrm{H}_{23} \mathrm{NO}_{4}$ : 436.1525 [M+Na] $]^{+}$; found: 436.1654. 


\subsection{Synthesis of 7}

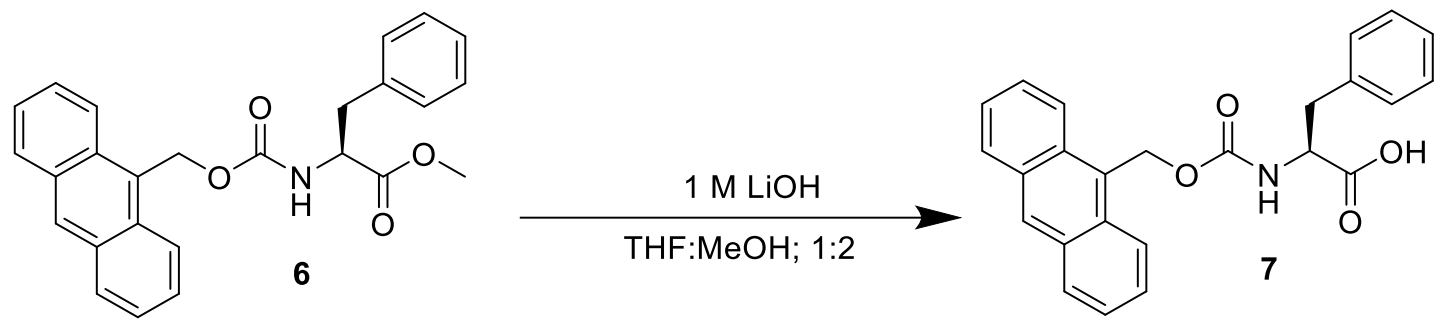

$6(1.2 \mathrm{~g}, 2.90 \mathrm{mmol})$ was dissolved in $15 \mathrm{~mL}$ THF and $30 \mathrm{~mL} \mathrm{MeOH}$. In the reaction mixture, 1 $\mathrm{M} \mathrm{LiOH}$ solution was slowly added for hydrolysis. The reaction mixture was stirred for $6 \mathrm{~h}$ and progress of the hydrolysis was monitored by TLC. Then $1 \mathrm{M} \mathrm{LiOH}$ solution was added in every 30 min interval according to the progress of the hydrolysis. The excess solvent was evaporated and remaining mixture was taken in the separating funnel. The mixture was very carefully washed with diethyl ether $(2 \times 20 \mathrm{~mL})$. The hydrolyzed solution was taken in the conical flask and acidified with $1 \mathrm{M} \mathrm{HCl}(\mathrm{pH} 2)$. The acidified solution was extracted three times with EtOAc $(3 \times 30 \mathrm{~mL})$ and dried over anhydrous $\mathrm{Na}_{2} \mathrm{SO}_{4}$. The solution was evaporated and solid yellow 7 was obtained. The solid yellow mass was recrystallized in dry THF.

Yield: 0.860 g (74\%); FT-IR (KBr): $\bar{v}=32094$ (s, NH), 1690 (s, amide I band), 1624 (s, amide I band), 1537 (s, amide II band) $\mathrm{cm}^{-1} ;{ }^{1} \mathrm{H}$ NMR (400 MHz, DMSO-d 6 ): $\delta=8.67$ (s, 1H, Amoc), 8.35-8.31 (d, $J=8.64 \mathrm{~Hz}, 2 \mathrm{H}$, Amoc), 8.13-8.11 (d, $J=8.16 \mathrm{~Hz}, 2 \mathrm{H}$, Amoc), 7.61-7.52 (m, 4H, Amoc), 7.50-7.48 (br m, 1H, NH), 7.19 (s, 5H, Phe), 6.05-5.95 (q, 2H, Amoc), 4.20 (br s, 1H, $\mathrm{C}^{\alpha} \mathrm{H}$ of Phe), 3.05-2.76 (m, 1H, $\mathrm{C}^{\beta} \mathrm{H}$ of Phe), 2.82-2.76 (m, 1H, $\mathrm{C}^{\beta} \mathrm{H}$ of Phe) ppm. MS (ESI): $m / z$ calcd for $\mathrm{C}_{25} \mathrm{H}_{21} \mathrm{NO}_{4}: 422.1368[\mathrm{M}+\mathrm{Na}]^{+}$; found: 422.1330 . 


\subsection{Synthesis of 8}

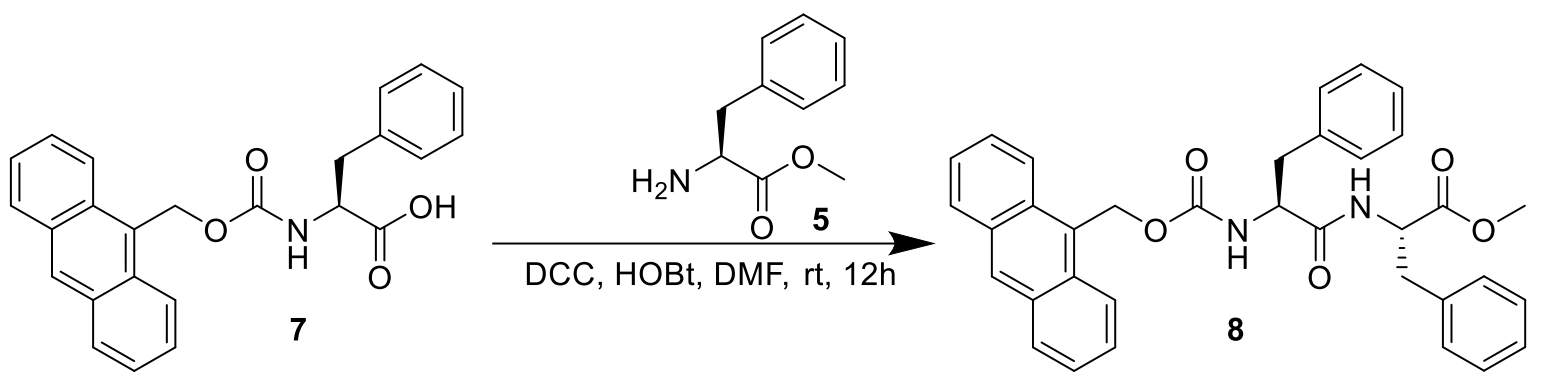

7 (1.0 g, $2.50 \mathrm{mmol})$ and $\mathrm{HOBt}(0.406 \mathrm{~g}, 3.0 \mathrm{mmol})$ was dissolved in $3 \mathrm{~mL}$ dry DMF. The coupling reagent DCC $(0.619 \mathrm{~g}, 3.0 \mathrm{mmol})$ was added to the reaction mixture. The reaction mixture was ice-cooled. The hydrochloride salt of $5(0.896 \mathrm{~g}, 5.0 \mathrm{mmol})$ was neutralized using saturated $\mathrm{Na}_{2} \mathrm{CO}_{3}(10 \mathrm{~mL})$ solution and the product was extracted using ethyl acetate $(3 \times 30$ $\mathrm{mL})$. The neutralized solution of $\mathbf{5}$ was added to the reaction mixture and allowed to stir for $12 \mathrm{~h}$. The product conversion was confirmed by TLC. The reaction mixture was filtered by sintered glass funnel (Borosil, G4) to remove urea by product. Ethyl acetate $(25 \mathrm{~mL})$ was added to the reaction mixture and washed with $1 \mathrm{M} \mathrm{HCl}(3 \times 30 \mathrm{~mL})$, saturated $\mathrm{Na}_{2} \mathrm{CO}_{3}$ solution $(3 \times 30 \mathrm{~mL})$. Solid yellow $\mathbf{8}$ was obtained after evaporating the solvent under reduced pressure. The solid product was dissolved in ACN and insoluble urea was removed by vacuum filtration. The ACN was evaporated at reduced pressure and solid mass was purified by flash chromatography using EtOAC : hexane (1:4) as eluent.

Yield: $1.2 \mathrm{~g}(85 \%)$; FT-IR (KBr): $\bar{v}=3296$ (s, NH), 1731 (s, COOMe), 1694 (s, amide I band), 1690 (s, amide I band), 1655 (s, amide I band), 1647 (s, amide I band), 1536 (s, amide II band) $\mathrm{cm}^{-1} ;{ }^{1} \mathrm{H}$ NMR (400 MHz, DMSO-d 6 ): $\delta=8.67$ (s, $1 \mathrm{H}$, Amoc), $8.45-8.43(\mathrm{~d}, J=7.44 \mathrm{~Hz}, 1 \mathrm{H}$, $\mathrm{NH}), 8.30-8.28(\mathrm{~d}, J=8.4 \mathrm{~Hz}, 2 \mathrm{H}$, Amoc), $8.13-8.11(\mathrm{~d}, \mathrm{~J}=8.08 \mathrm{~Hz}, 2 \mathrm{H}$, Amoc), 7.59-7.26 
(m, 4H, Amoc), 7.33-7.31 (d, $J=8.72 \mathrm{~Hz}, 1 \mathrm{H}, \mathrm{NH}), 7.28-7.19$ (br, m, 10H, ph of Phe), 5.995.89 (m, 2H, Amoc), 4.51-4.46 (m, 1H, $\mathrm{C}^{\alpha} \mathrm{H}$ of Phe), 4.34-4.30 (m, 1H, $\mathrm{C}^{\alpha} \mathrm{H}$ of Phe), 3.56 (s, $\left.3 \mathrm{H}, \mathrm{OCH}_{3}\right), 3.06-2.87$ (m, 3H, $\mathrm{C}^{\beta} \mathrm{Hs}$ of Phe), 2.66-2.60 (m, 1H, $\mathrm{C}^{\beta} \mathrm{Hs}$ of Phe) ppm; MS (ESI): $m / z$ calcd for $\mathrm{C}_{35} \mathrm{H}_{32} \mathrm{~N}_{2} \mathrm{O}_{5}: 583.2209[\mathrm{M}+\mathrm{Na}]^{+}$; found: 583.2279 .

\subsection{Synthesis of 1}

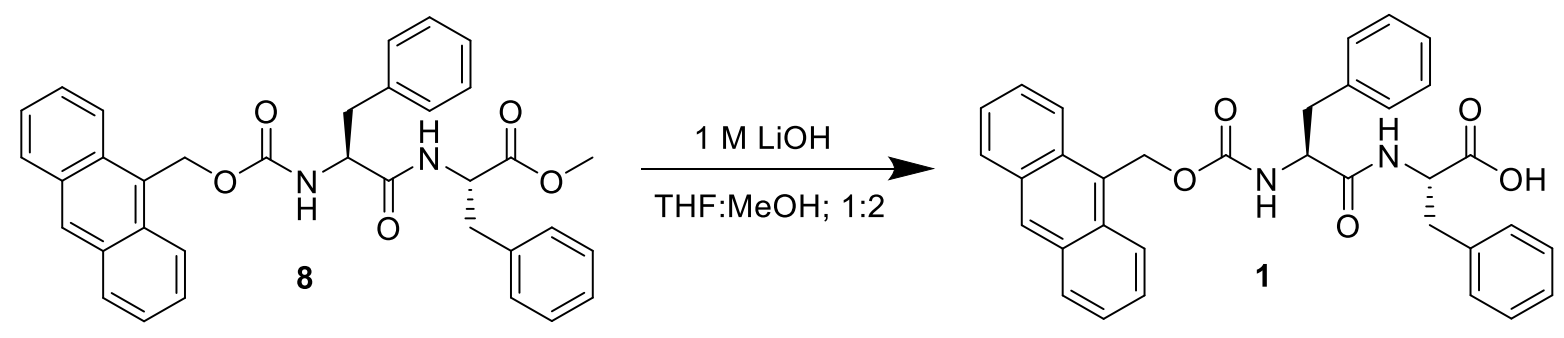

8 (0.600 g, $1.07 \mathrm{mmol})$ was completely solubilized in the mixture of THF:MeOH (1:2, $30 \mathrm{~mL})$.

In the reaction mixture, $2 \mathrm{~mL} 1 \mathrm{M} \mathrm{LiOH}$ solution was added slowly. The progress of the hydrolysis was monitored by TLC and reaction mixture was stirred up to $6 \mathrm{~h}$ for complete hydrolysis. After the completion of the reaction, excess solvent was evaporated and diluted with $30 \mathrm{~mL}$ of distilled water. The aqueous solution of the product was taken into the separating funnel and slowly washed with diethyl ether $(20 \mathrm{~mL})$. The aqueous layer was collected and cooled in an ice bath. Then, the solution was acidified with $1 \mathrm{M} \mathrm{HCl}(\mathrm{pH}$ 2). The product was extracted with ethyl acetate $(3 \times 30 \mathrm{~mL})$. The ethyl acetate layer was dried over anhydrous $\mathrm{Na}_{2} \mathrm{SO}_{4}$ and evaporated under reduced pressure to obtain $\mathbf{1}$ as yellow product. The yellow product was recrystallized in dry THF.

Yield: $0.489 \mathrm{~g}(83 \%)$; FT-IR (KBr): $\bar{v}=3289$ (s, NH), 1710 (s, COOH), 1690 (s, amide I band), 1657 (s, amide I band), 1650 (s, amide I band), 1533 (s, amide II band) $\mathrm{cm}^{-1} ;{ }^{1} \mathrm{H}$ NMR (400 
MHz, DMSO-d $\left.\mathrm{d}_{6}\right): \delta=8.67$ (s, $1 \mathrm{H}$, Amoc), 8.29-8.23 (m, 3H, 2H of Amoc and NH), 8.13-8.11 (d, $J=7.84 \mathrm{~Hz}, 2 \mathrm{H}$, Amoc), 7.59-7.52 (m, 4H, Amoc), 7.31-7.29 (d, J=8.8 Hz, 1H, NH), 7.24$7.13\left(\mathrm{~m}, 11 \mathrm{H}, 10 \mathrm{H}\right.$ of ph of Phe and NH), 5.97-5.89 (m, 2H, Amoc), 4.47-4.30 (m, 2H, C ${ }^{\alpha} \mathrm{H}$ of Phe), 3.09-3.05 (m, 2H, $\mathrm{C}^{\beta} \mathrm{H}$ of Phe), 2.95-2.88 (m, 2H, $\mathrm{C}^{\beta} \mathrm{H}$ of Phe) ppm; ${ }^{13} \mathrm{C}$ NMR (100 MHz, DMSO-d $\left.{ }_{6}\right): \delta=173.30,172 . .05,156.48,138.48,137.88,131.40,130.95,129.72,129.64$, $129.38,129.13,128.70,128.48,127.53,127.11,126.71,125.74,124.64,58.67,56.57,54.00$, 37.88, 37.23 ppm; HRMS (ESI): $m / z$ calcd for $\mathrm{C}_{34} \mathrm{H}_{30} \mathrm{~N}_{2} \mathrm{O}_{5}: 569.2052[\mathrm{M}+\mathrm{Na}]^{+}$; found: 569.2059.

\section{Mass ${ }^{1} \mathrm{H}$ and ${ }^{13} \mathrm{C}$ NMR Spectra}
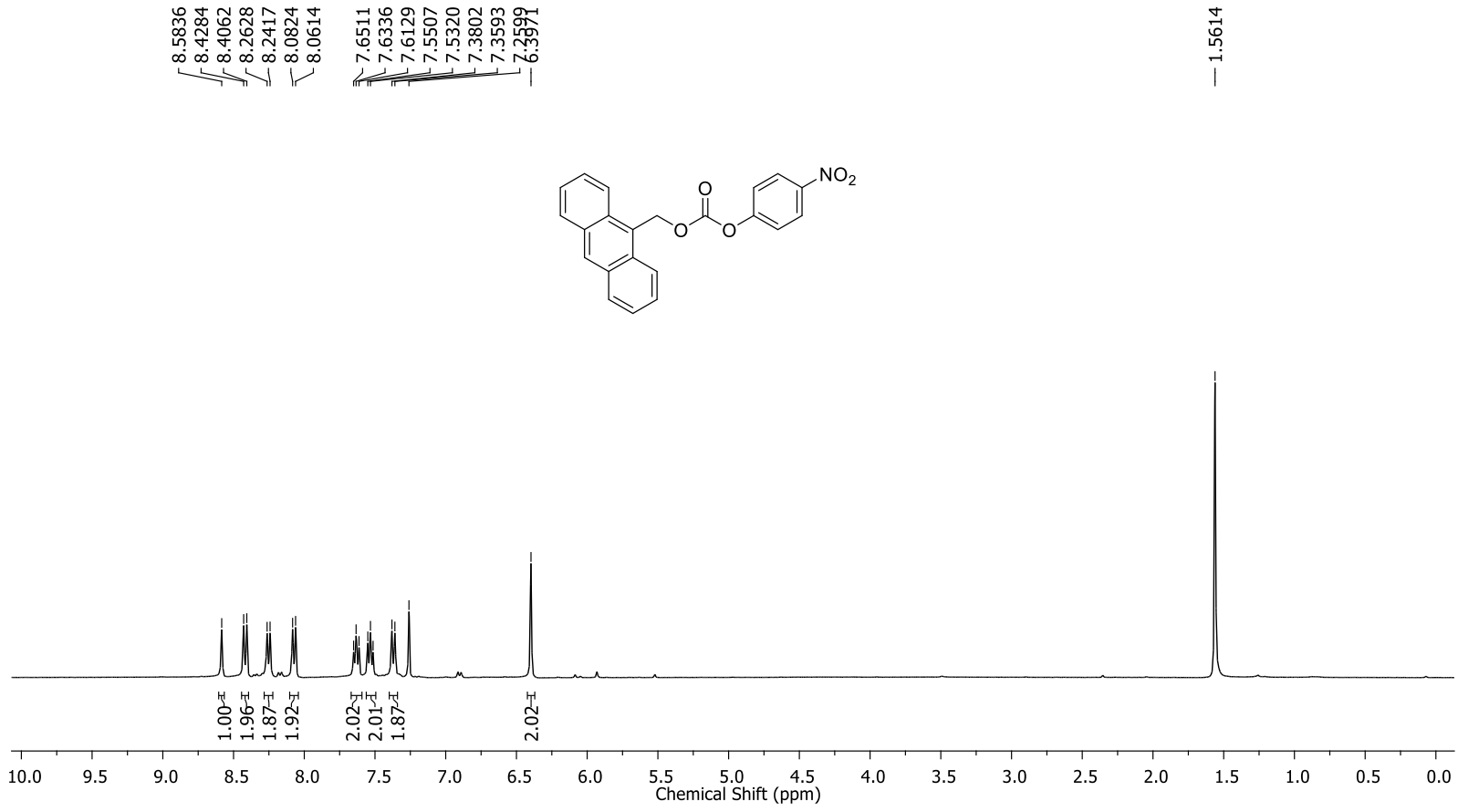

Figure S1. ${ }^{1} \mathrm{H}$ NMR $\left(400 \mathrm{MHz}, \mathrm{CDCl}_{3}\right)$ spectrum of 4. 


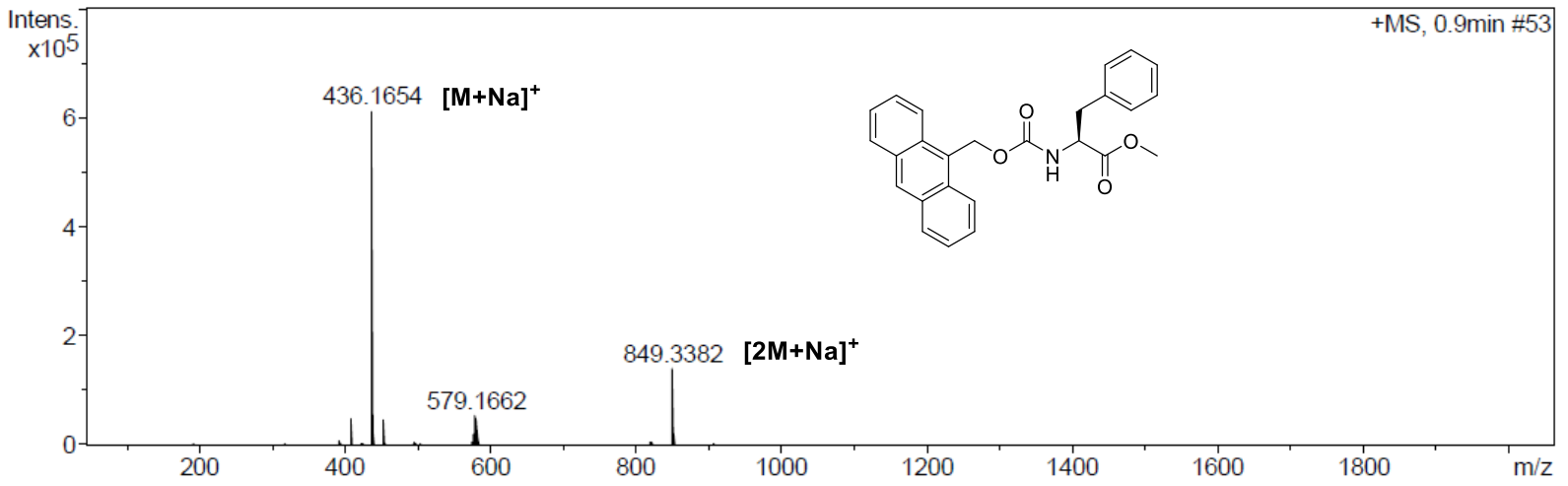

Figure S2. ESI-MS spectrum of 6.

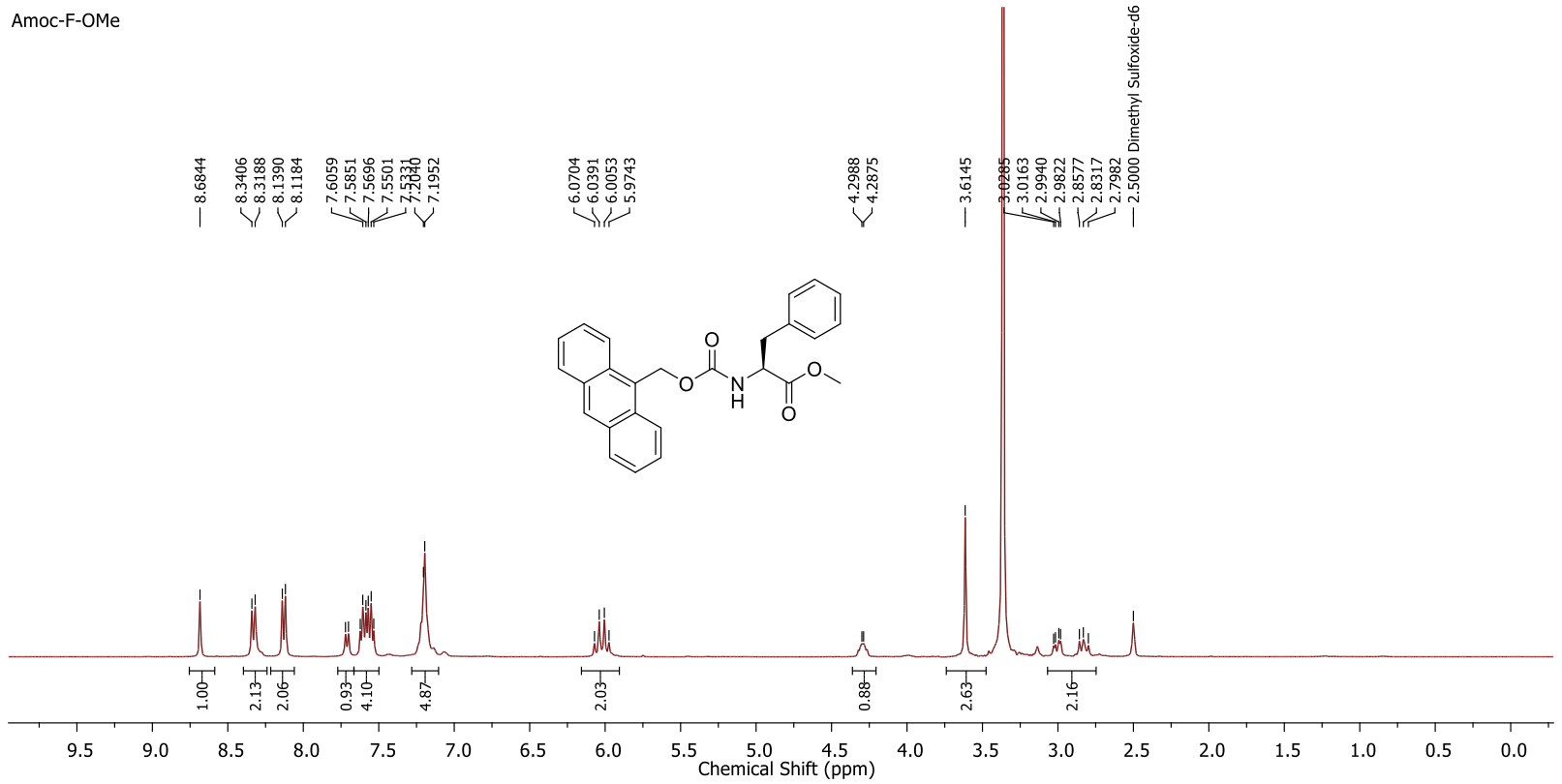

Figure S3. ${ }^{1} \mathrm{H}$ NMR (400 MHz, DMSO-d $)$ spectrum of 6. 


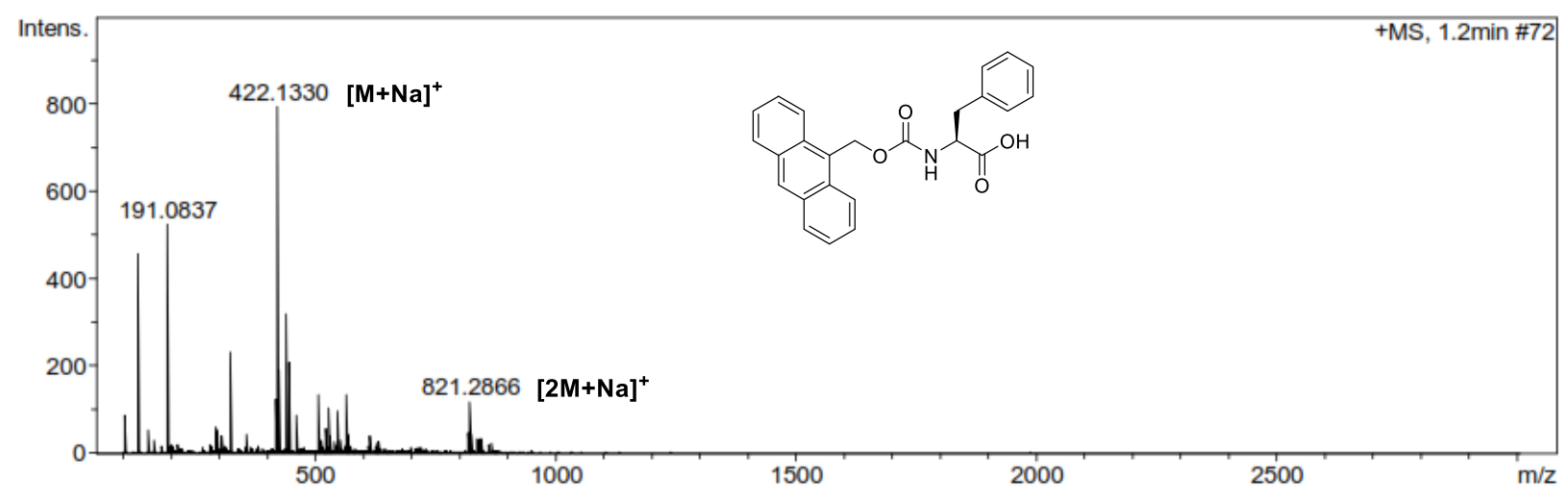

Figure S4. ESI-MS spectrum of 7.

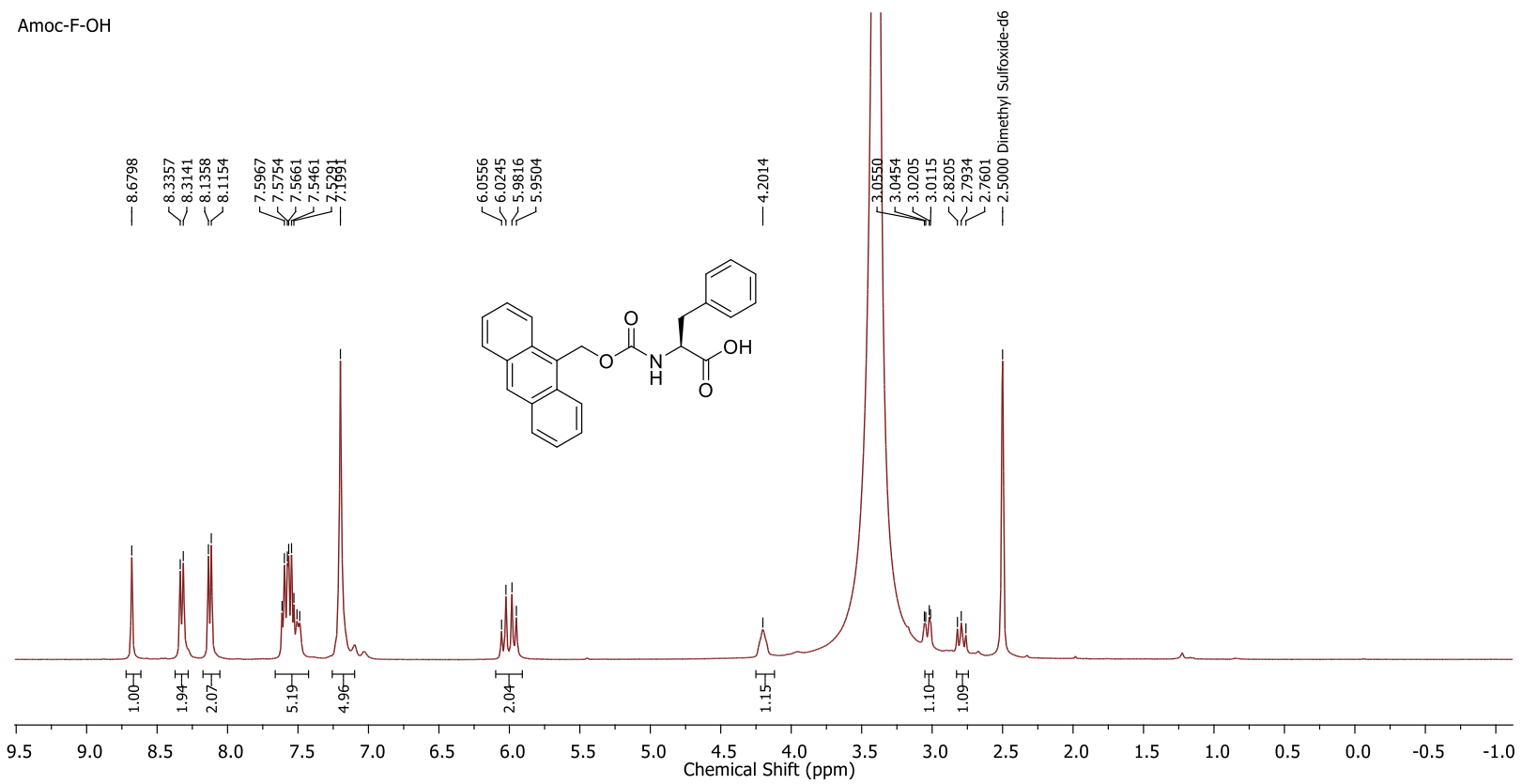

Figure S5. ${ }^{1} \mathrm{H}$ NMR (400 MHz) spectrum of 7 in DMSO-d 6. 


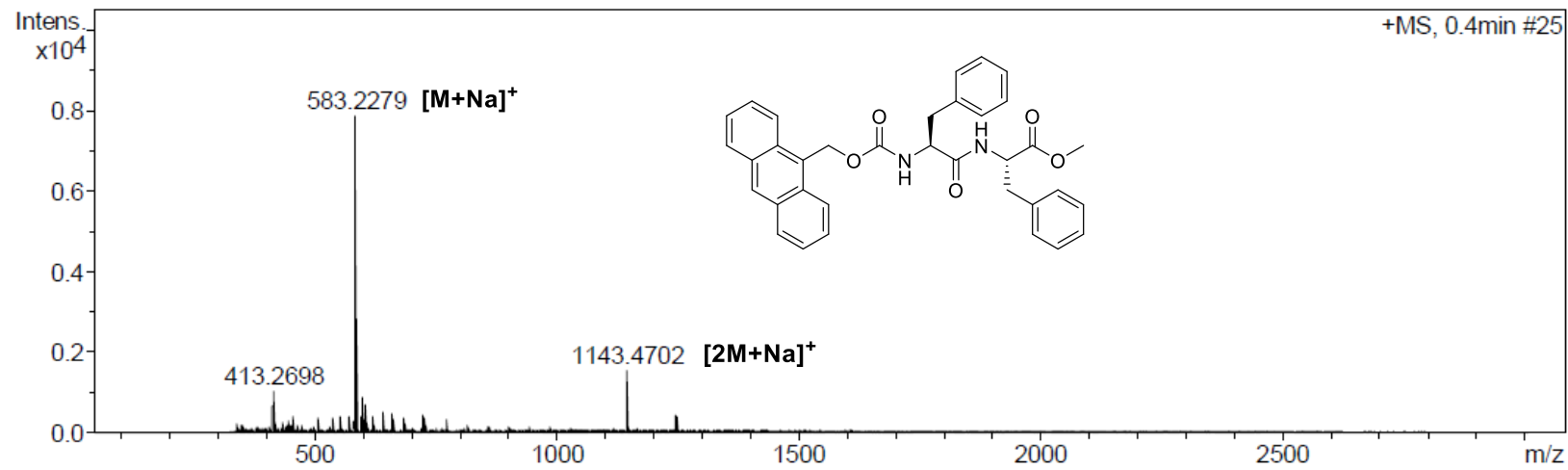

Figure S6. ESI-MS spectrum of 8.

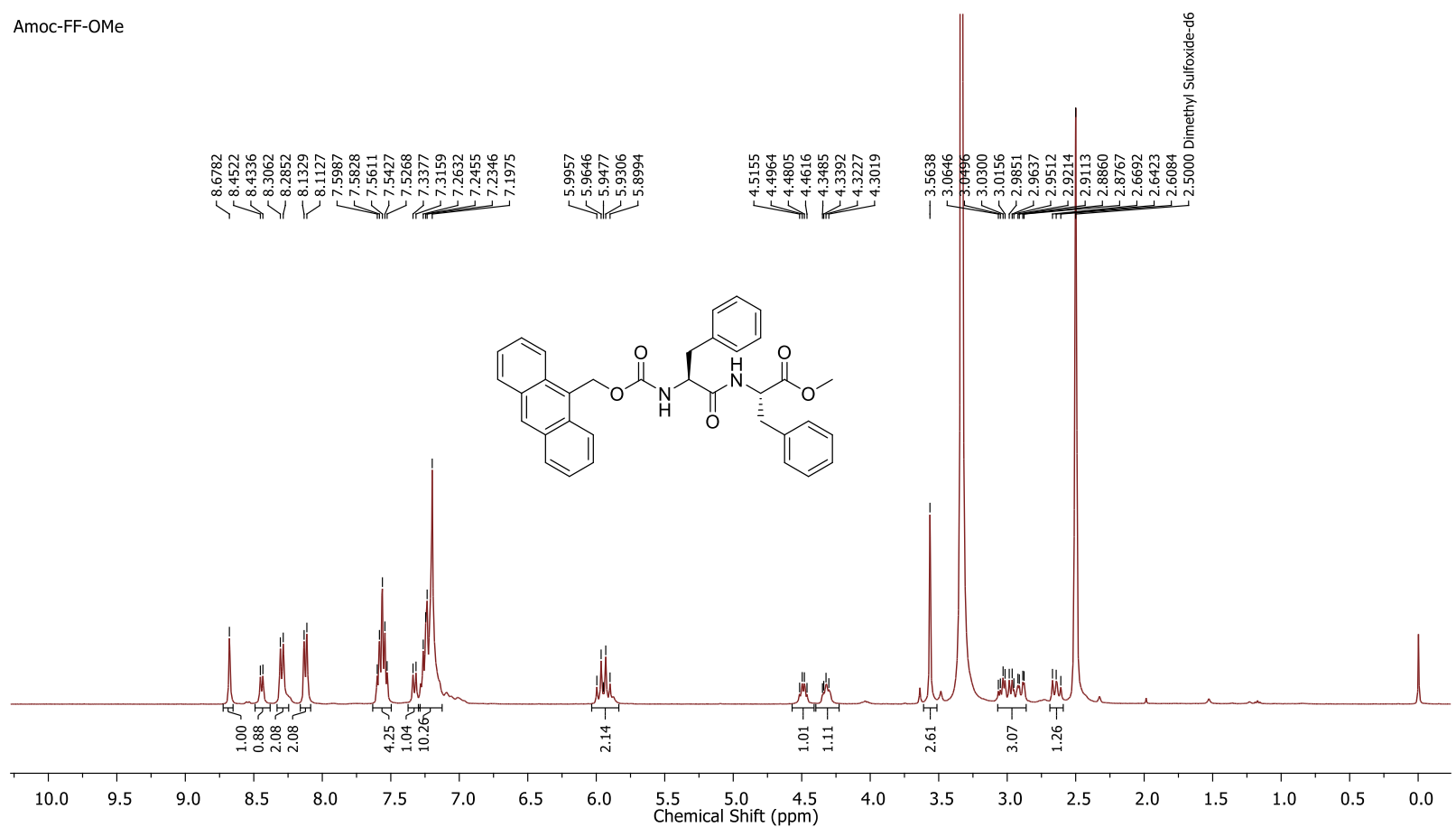

Figure S7. ${ }^{1} \mathrm{H}$ NMR (400 MHz) spectrum of 8 in DMSO-d 6. 


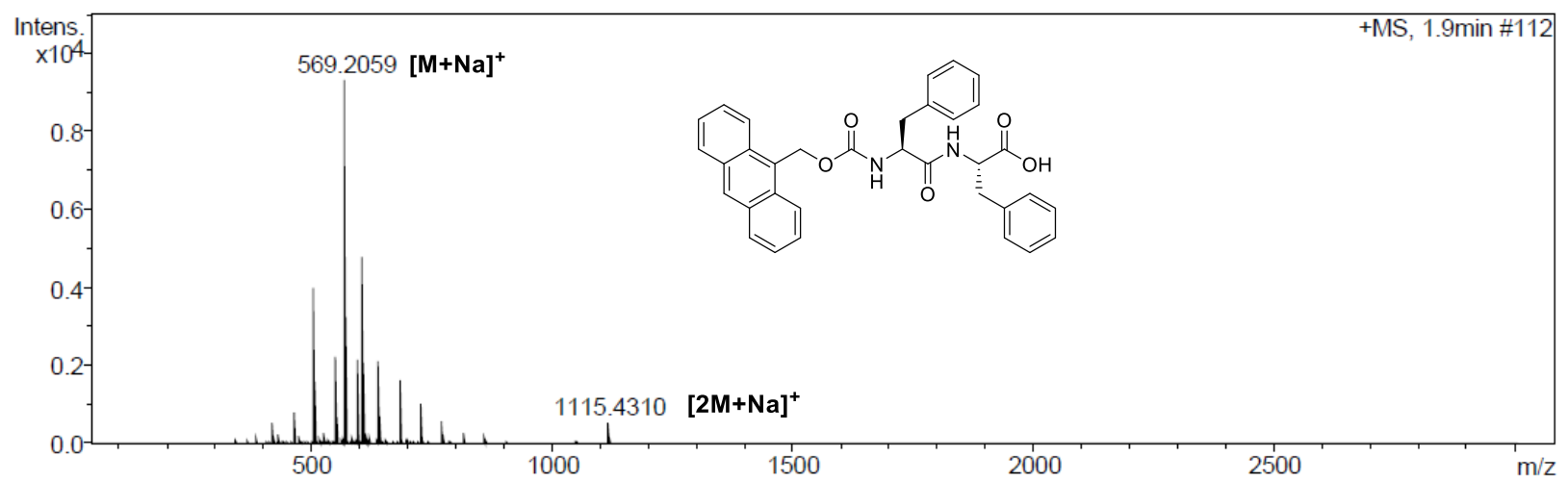

Figure S8. HR-MS spectrum of 1 .

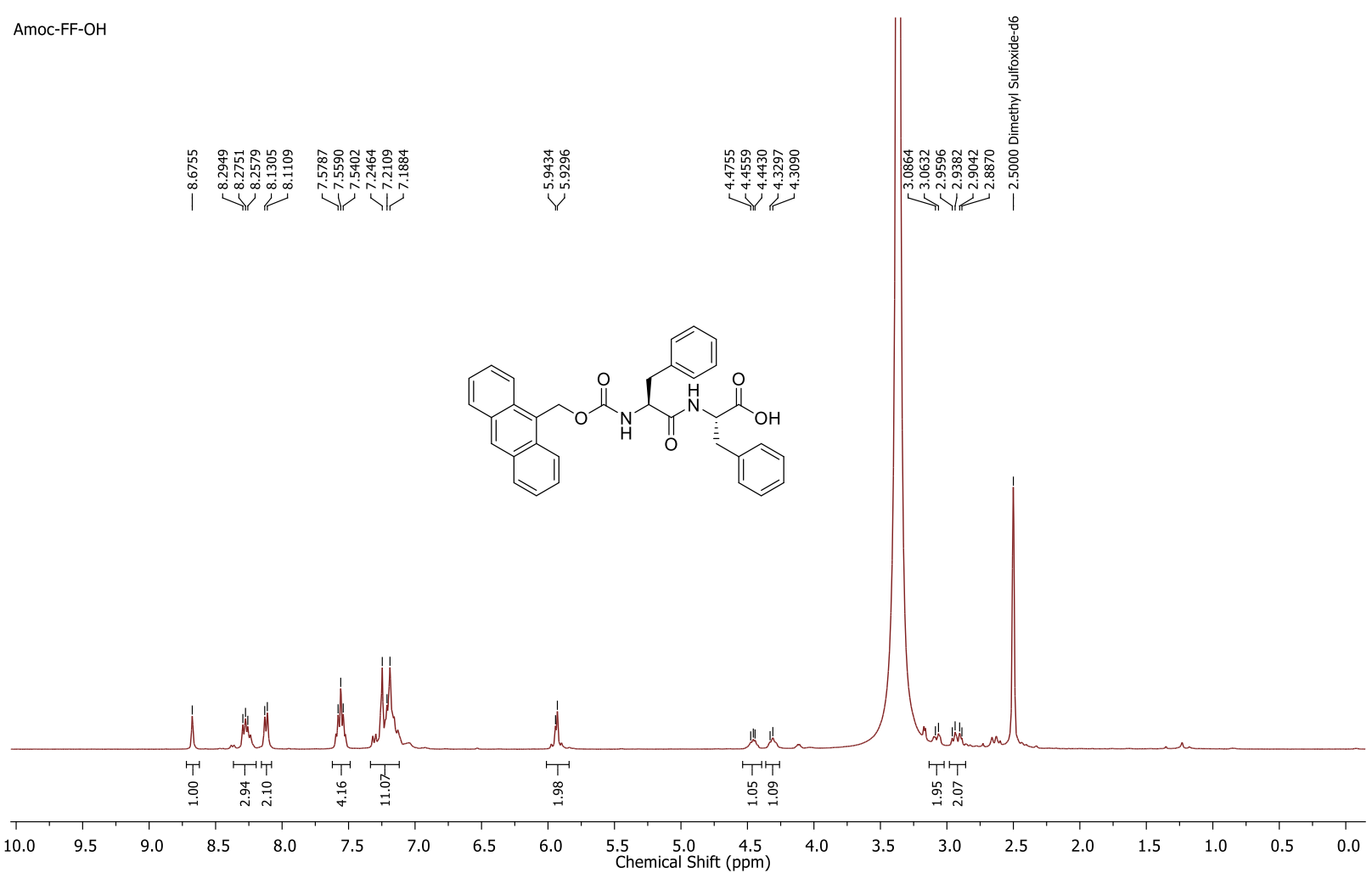

Figure S9. ${ }^{1} \mathrm{H}$ NMR (400 MHz) spectrum of 1 in DMSO-d 6. 

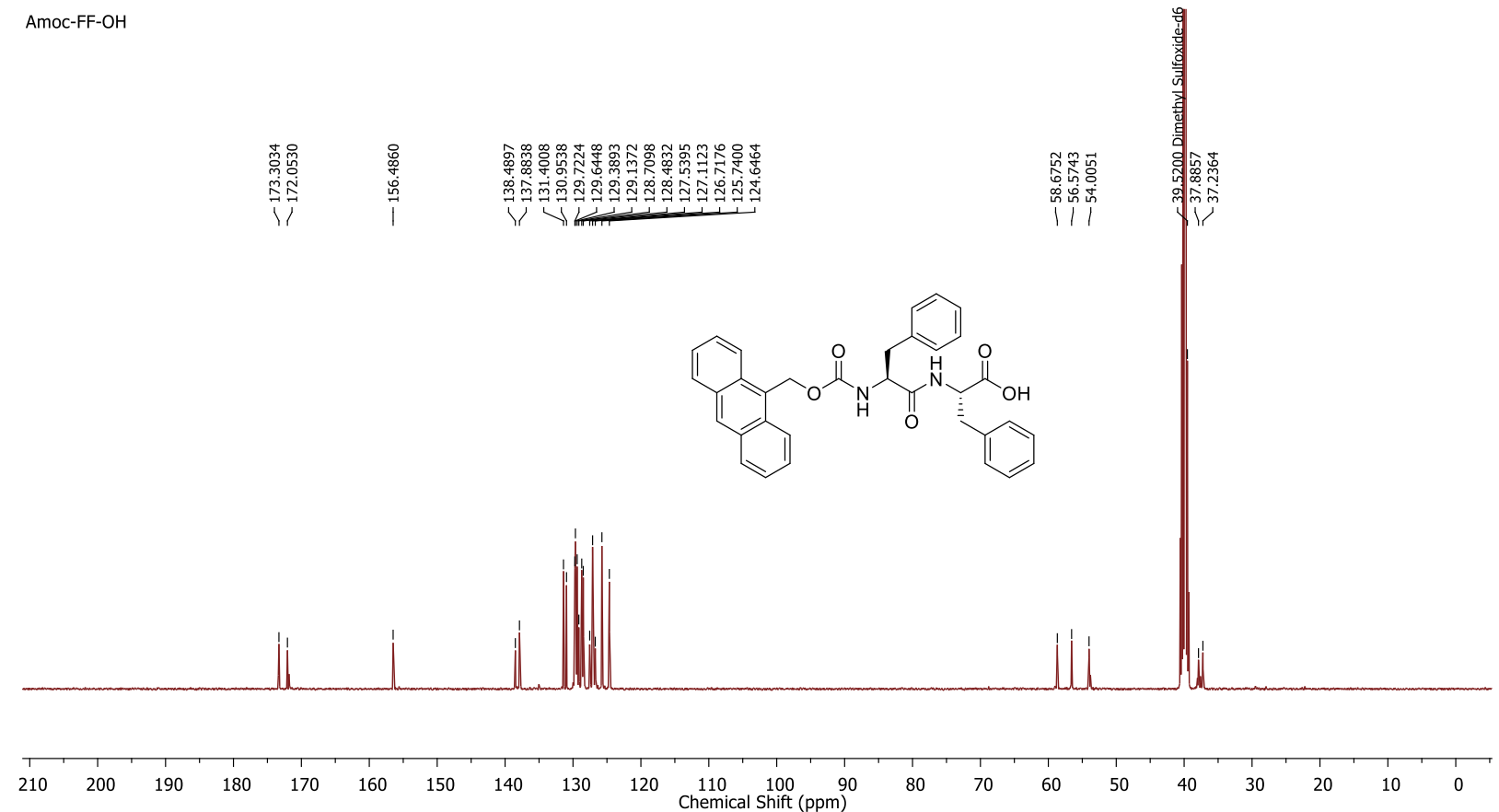

Figure S10. ${ }^{13} \mathrm{C}$ NMR (100 MHz) spectrum of 1 in DMSO-d 6 .

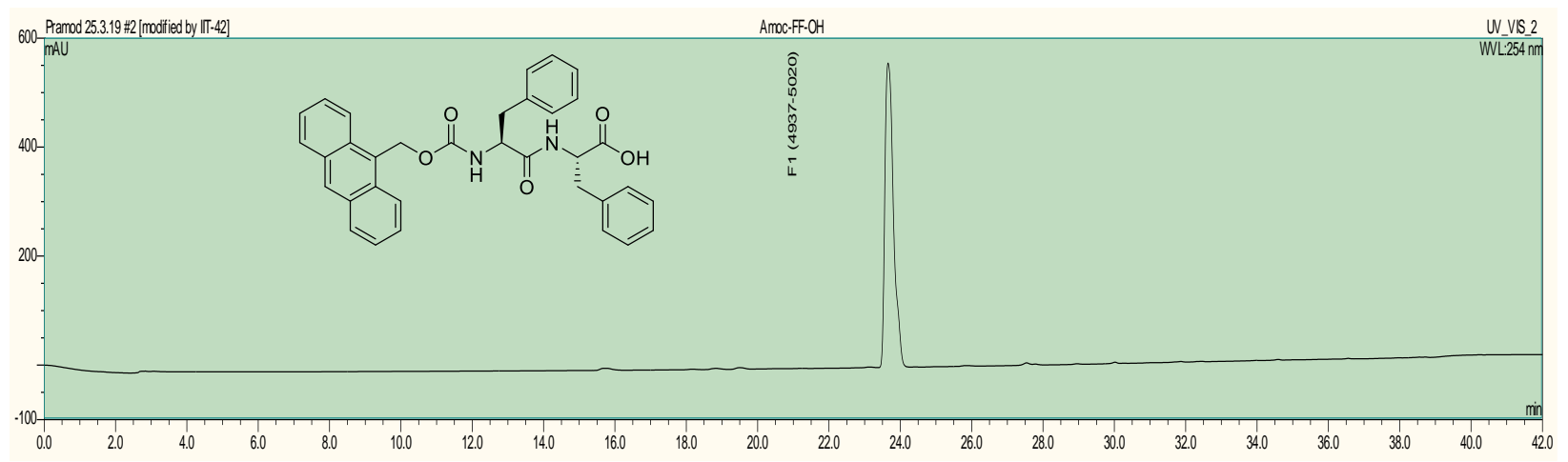

Figure S11. HPLC chromatogram $(\lambda=254 \mathrm{~nm})$ of $\mathbf{1}$. 
Table S1. Preparation of the hydrogels 1-5 with different concentrations of CD and their physical nature

\begin{tabular}{|c|c|c|c|c|c|c|}
\hline $\begin{array}{c}\text { S. } \\
\text { No. }\end{array}$ & $\begin{array}{c}\text { Peptide } \\
(\mathrm{mmol} \mathrm{L} \\
1)\end{array}$ & $\begin{array}{c}\mathrm{CD} \\
(\mathrm{mmol} \mathrm{L} \\
\left.{ }^{1}\right)\end{array}$ & $\begin{array}{c}\text { Peptide/CD } \\
(\mathrm{molar} \\
\text { ratio })\end{array}$ & $\begin{array}{c}\text { Temperature, } \\
\mathrm{pH}\end{array}$ & Hydrogel & Nature of Hydrogel \\
\hline 1 & 20 & - & - & $37^{\circ} \mathrm{C}, 7.4$ & Yes & $\begin{array}{c}\text { Strong, } \\
\text { nonhomogeneous }\end{array}$ \\
\hline 2 & 20 & 5 & $1: 0.25$ & $37^{\circ} \mathrm{C}, 7.4$ & Yes & Weak homogeneous \\
\hline 3 & 20 & 10 & $1: 0.50$ & $37^{\circ} \mathrm{C}, 7.4$ & Yes & $\begin{array}{c}\text { Homogeneous, self- } \\
\text { recoverable }\end{array}$ \\
\hline 4 & 20 & 20 & $1: 1$ & $37^{\circ} \mathrm{C}, 7.4$ & Yes & $\begin{array}{c}\text { Homogeneous, self- } \\
\text { recoverable, } \\
\text { injectable }\end{array}$ \\
\hline 5 & 20 & 40 & $1: 2$ & $37^{\circ} \mathrm{C}, 7.4$ & $\begin{array}{c}\text { Yes, } \\
\text { Unstable }\end{array}$ & Very weak, \\
\hline
\end{tabular}



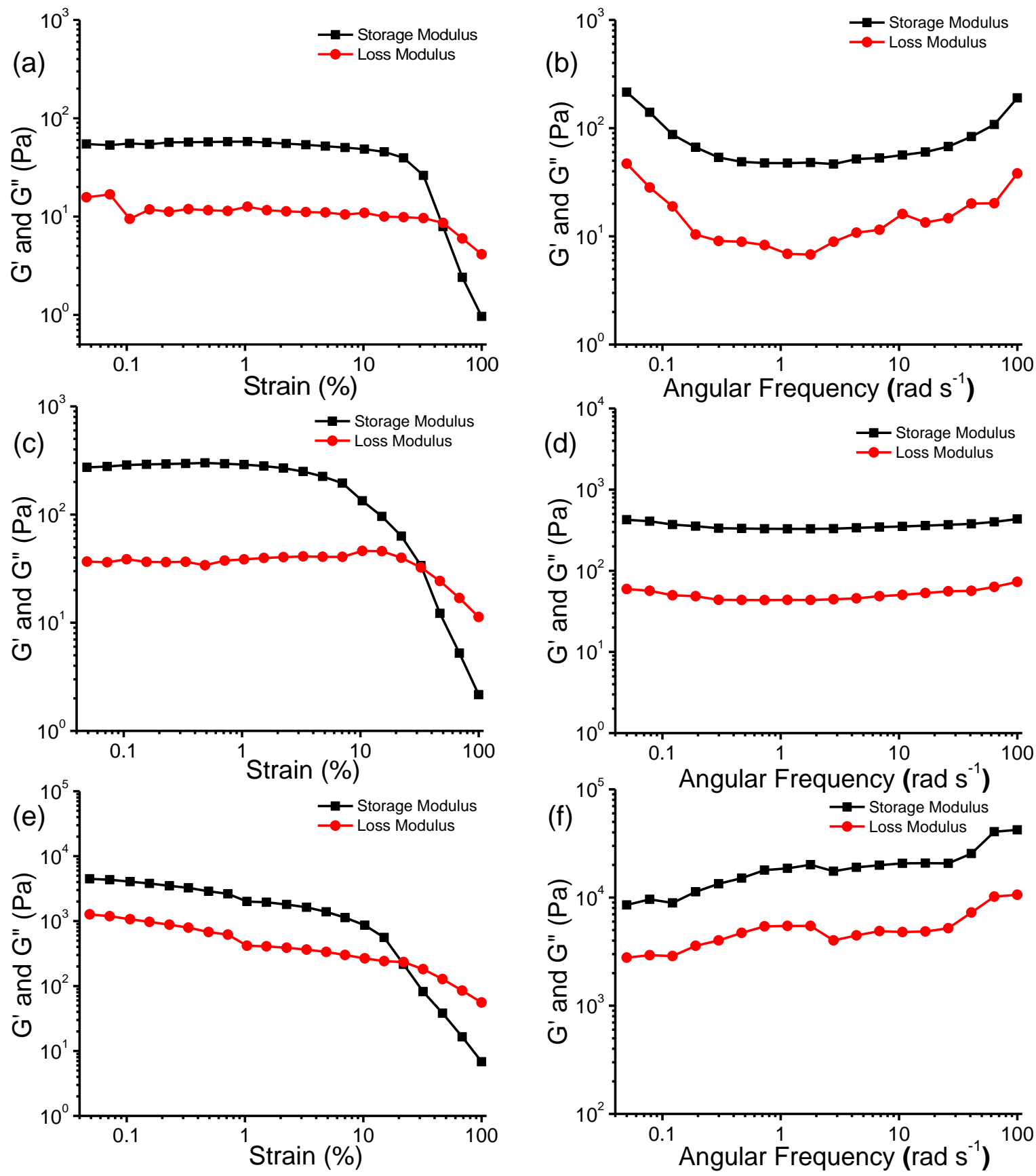

Figure S12. The amplitude and frequency sweep data of (a, b) hydrogel 2, (c, d) hydrogel 3, and (e, f) hydrogel 5, respectively. 
(a)

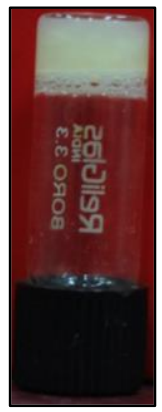

Gel

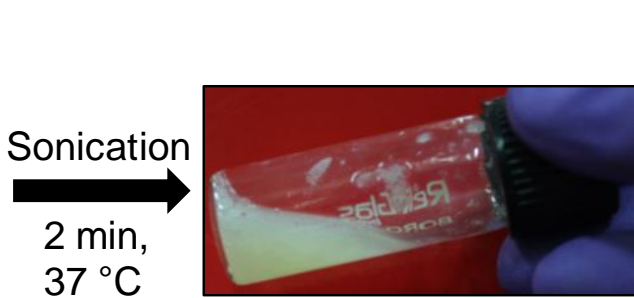

Sol

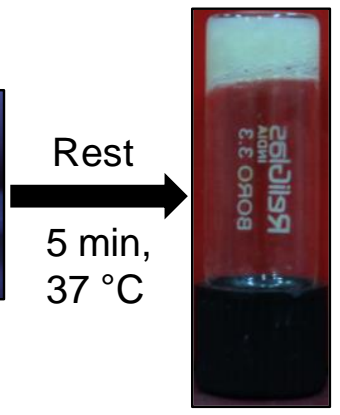

Gel

(b)
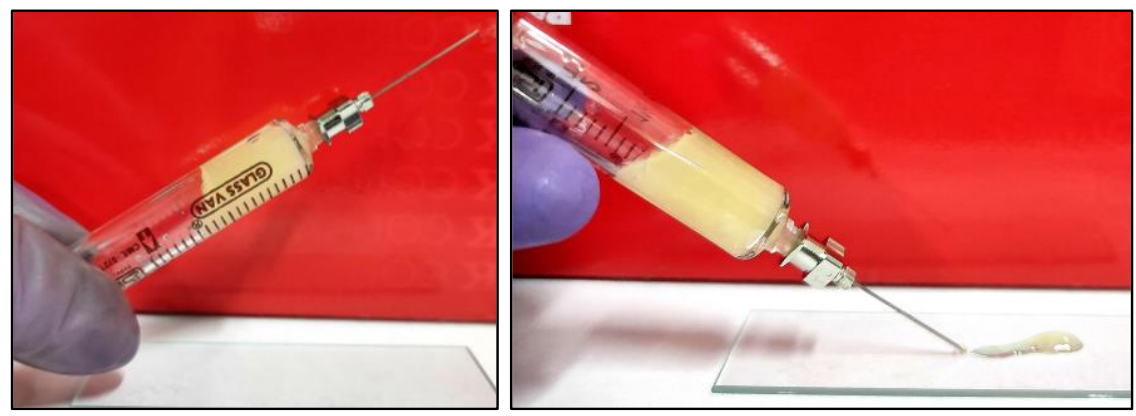

Figure S13. The optical photographs of hydrogel 4 showing: (a) reversible gel-sol-gel conversion; (b) syringe injectability. 


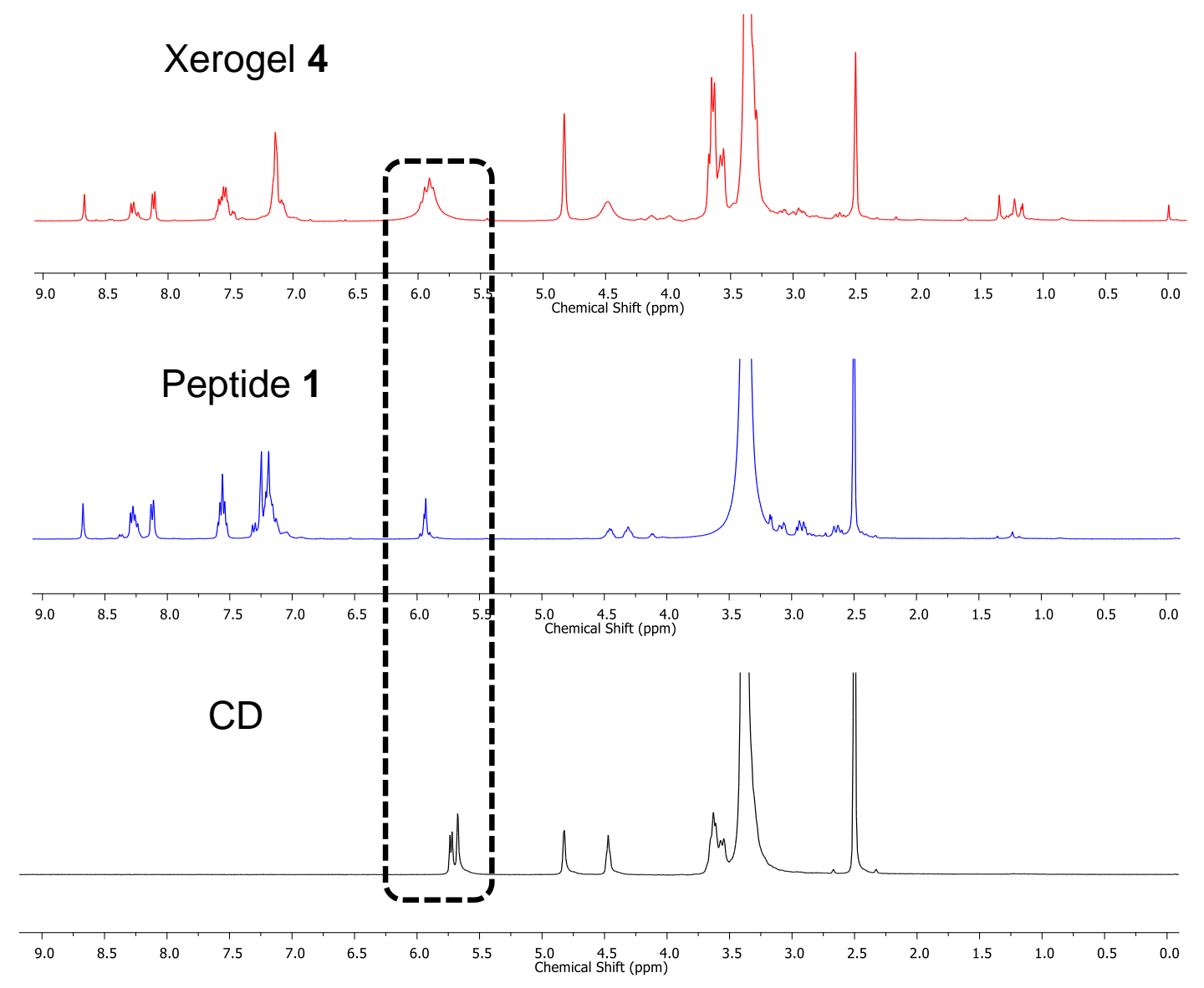

Figure S14. ${ }^{1} \mathrm{H}$ NMR $\left(400 \mathrm{MHz}, 25^{\circ} \mathrm{C}\right)$ data of CD, peptide and xerogel 4 in DMSO-d 6 showing the change in chemical shift value of xerogel 4.

Table S2. ${ }^{1} \mathrm{H}$ NMR $\left(400 \mathrm{MHz}, 25^{\circ} \mathrm{C}\right)$ data of the free CD and CD in xerogel 4 in DMSO-d 6

\begin{tabular}{|c|c|c|c|c|}
\hline S. No. & $\begin{array}{c}\text { CD } \\
\text { (Proton) }\end{array}$ & $\begin{array}{c}\text { CD } \\
\delta(\mathrm{ppm}, \text { free })\end{array}$ & $\begin{array}{c}\text { Xerogel 4 } \\
\delta(\mathrm{ppm})\end{array}$ & $\begin{array}{c}\text { Xerogel 4 } \\
\Delta \delta(\mathrm{ppm})\end{array}$ \\
\hline 1 & H-1 & 4.8219 & 4.8320 & 0.0101 \\
\hline 2 & H-3 and H-5 & $3.5721-3.5456$ & $3.5814-3.5561$ & $0.0093-0.0105$ \\
\hline 3 & H-6,6 & $3.6292-3.6115$ & $3.6740-3.6288$ & $0.0448-0.0173$ \\
\hline 4 & H-4 & $3.3($ broad $)$ & $3.3227-3.2935$ & - \\
\hline 5 & H-2 & $3.3($ broad $)$ & $3.3227-3.2935$ & - \\
\hline 6 & $\mathrm{OH}(2)$ & $5.7359-5.7190$ & $5.9790-5.8801$ & $0.2431-0.1611$ \\
\hline 7 & $\mathrm{OH}(3)$ & 5.6752 & $5.9790-5.8801$ & $0.3038-0.2049$ \\
\hline 8 & $\mathrm{OH}(6)$ & 4.4709 & 4.4823 & 0.0114 \\
\hline
\end{tabular}


Table S3. ${ }^{1} \mathrm{H}$ NMR $\left(400 \mathrm{MHz}, 25{ }^{\circ} \mathrm{C}\right.$ ) data of the peptide in xerogel 4 in DMSO-d 6

\begin{tabular}{|c|c|c|c|c|}
\hline $\begin{array}{c}\text { S. } \\
\text { No. }\end{array}$ & $\begin{array}{c}\text { Peptide 1 } \\
\text { (Proton) }\end{array}$ & $\begin{array}{c}\text { Peptide 1 } \\
\delta(\mathrm{ppm}, \text { free) }\end{array}$ & $\begin{array}{c}\text { Xerogel 4 } \\
\delta(\mathrm{ppm}, \text { free) }\end{array}$ & $\begin{array}{c}\text { Xerogel 4 } \\
\Delta \delta(\mathrm{ppm})\end{array}$ \\
\hline 1 & $\mathrm{H}-10$ (Amoc) & 8.6755 & 8.6694 & 0.0061 \\
\hline 2 & $\mathrm{H}-1$ and H-8 (Amoc) & $8.2949-8.2376$ & $8.2967-8.2750$ & $0.0018-0.0374$ \\
\hline 3 & $\mathrm{H}-4$ and H-5 (Amoc) & $8.1305-8.1109$ & $8.1252-8.1048$ & $0.0053-0.0061$ \\
\hline 4 & $\begin{array}{c}\mathrm{H}-2, \mathrm{H}-3, \mathrm{H}-6 \text { and H-7 } \\
\text { (Amoc) }\end{array}$ & $7.5942-7.5243$ & $7.6093-7.5220$ & $0.0151-0.0023$ \\
\hline 5 & $-\mathrm{CH}_{2}$ (Amoc) & $5.9749-5.8979$ & $5.9790-5.8801$ & $0.0041-0.0178$ \\
\hline 6 & $-\mathrm{NH}-$ & $8.2949-8.2376$ & $7.6093-7.4679$ & Shifting \\
\hline 7 & $-\mathrm{NH}-$ & $7.3173-7.2953$ & $7.6093-7.4679$ & Shifting \\
\hline 8 & $\mathrm{Ph}(\mathrm{Phe} / \mathrm{Tyr})$ & $7.2464-7.1300$ & $7.1412-7.0929$ & $0.1052-0.0371$ \\
\hline 9 & $\mathrm{C}^{\alpha} \mathrm{H}(\mathrm{Phe} / \mathrm{Tyr})$ & $4.4755-4.3090$ & $4.1324-3.9938$ & $0.3431-0.3152$ \\
\hline 10 & $\mathrm{C}^{\beta} \mathrm{H}(\mathrm{Phe} / \mathrm{Tyr})$ & $3.0980-2.8870$ & $3.1070-2.9072$ & $0.009-0.0202$ \\
\hline
\end{tabular}

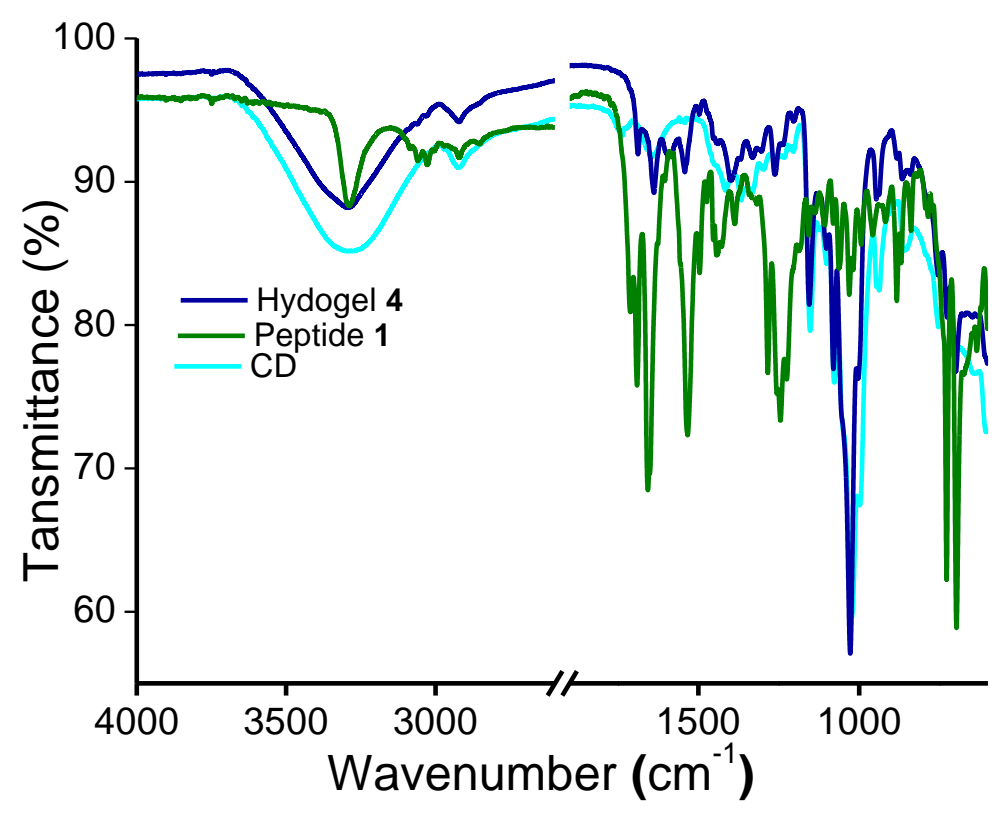

Figure S15. The FTIR spectra of the CD, peptide 1 and hydrogel 4. 

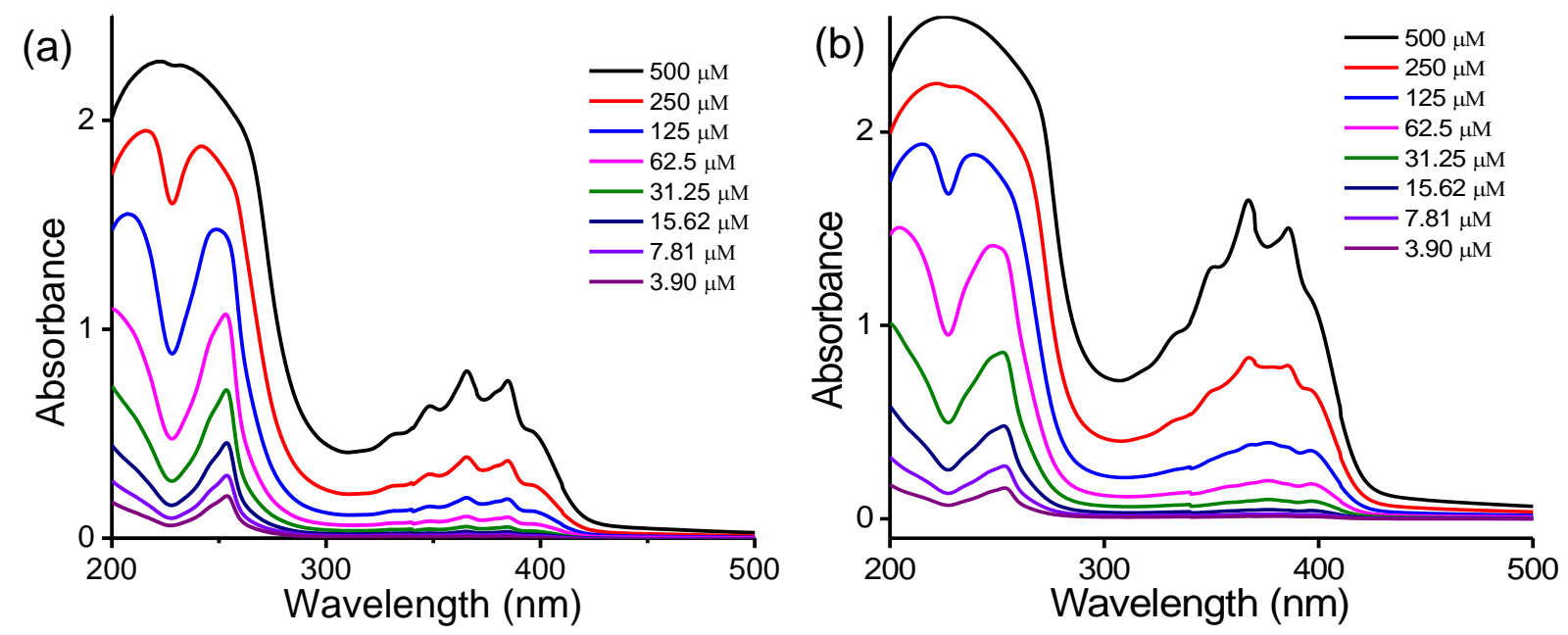

Figure S16. The concentration-dependent UV-vis spectra of (a) hydrogel 1 and (b) hydrogel 4, respectively.

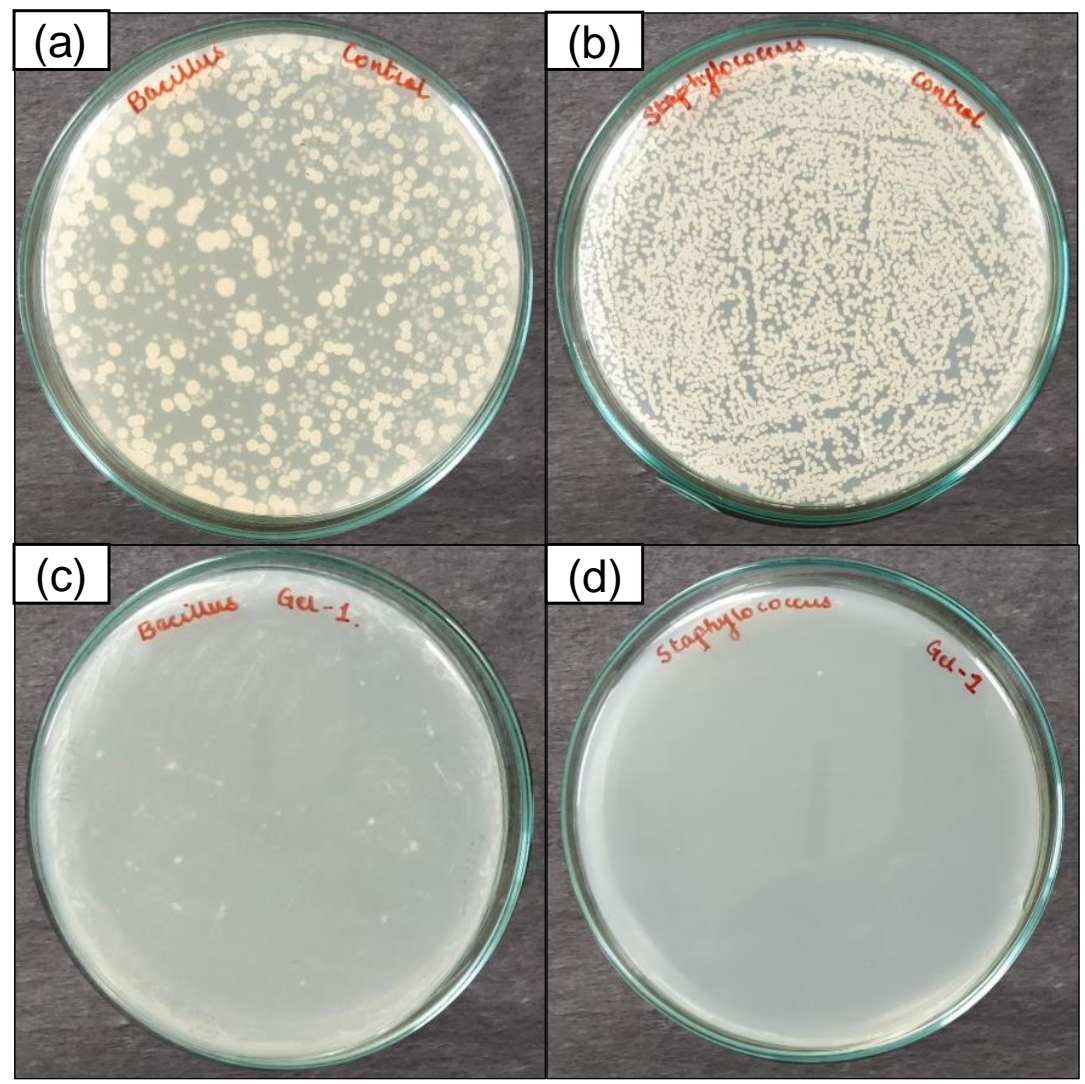

Figure S17. Optical photographs of antibacterial activity: (a, b) are control; (c, d) are hydrogel 4 against B. subtilis and $S$. aureus bacteria, respectively. 


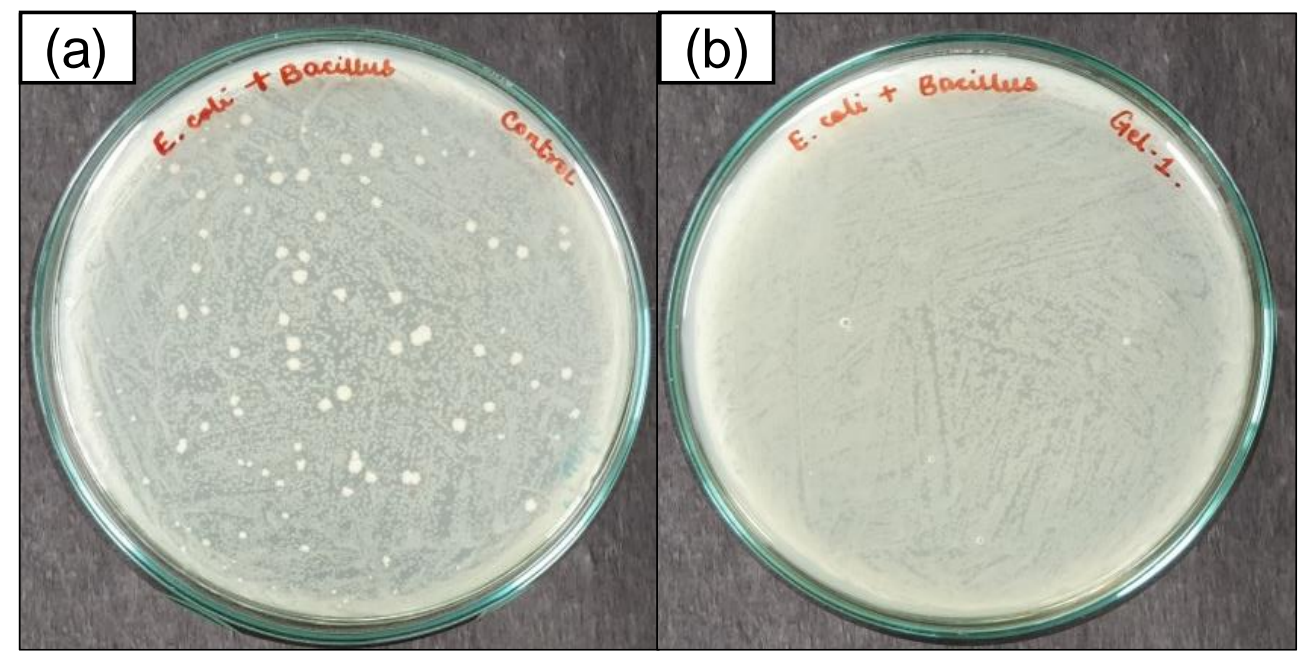

Figure S18. Optical photographs of antibacterial activity against mixture of $E$. coli and $B$. subtilis bacteria: (a) control; (b) hydrogel 4 showing selective inhibition of the growth of $B$. subtilis bacteria.

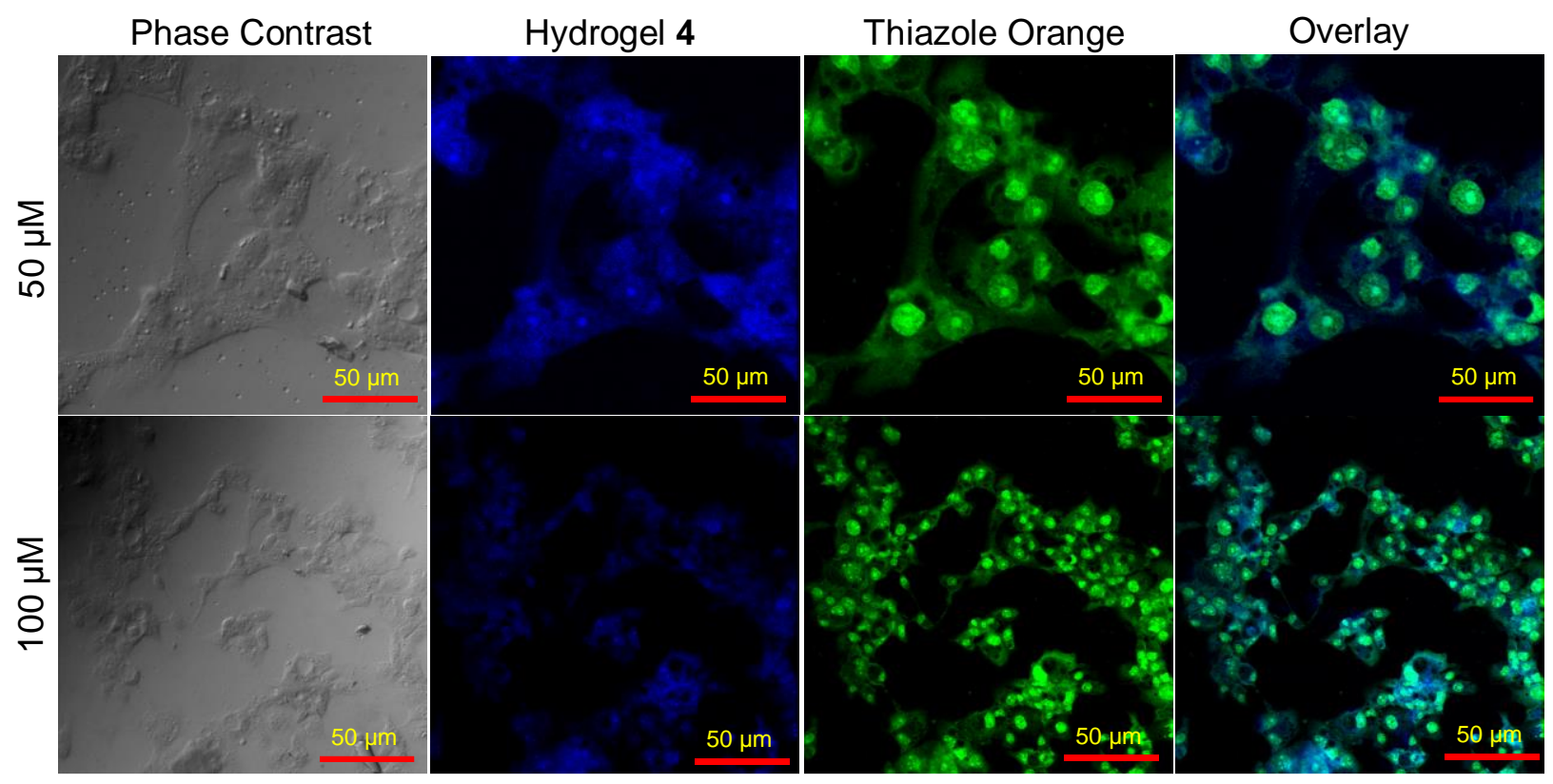

Figure S19. Confocal microscopy images of A431 cells treated with hydrogel 4 (50 and 100 $\mu \mathrm{M})$ and thiazole orange $(100 \mu \mathrm{M})$ for $4 \mathrm{~h}$ at excitation wavelengths $\lambda_{\mathrm{ex}}=405$ and $488 \mathrm{~nm}$, respectively. 


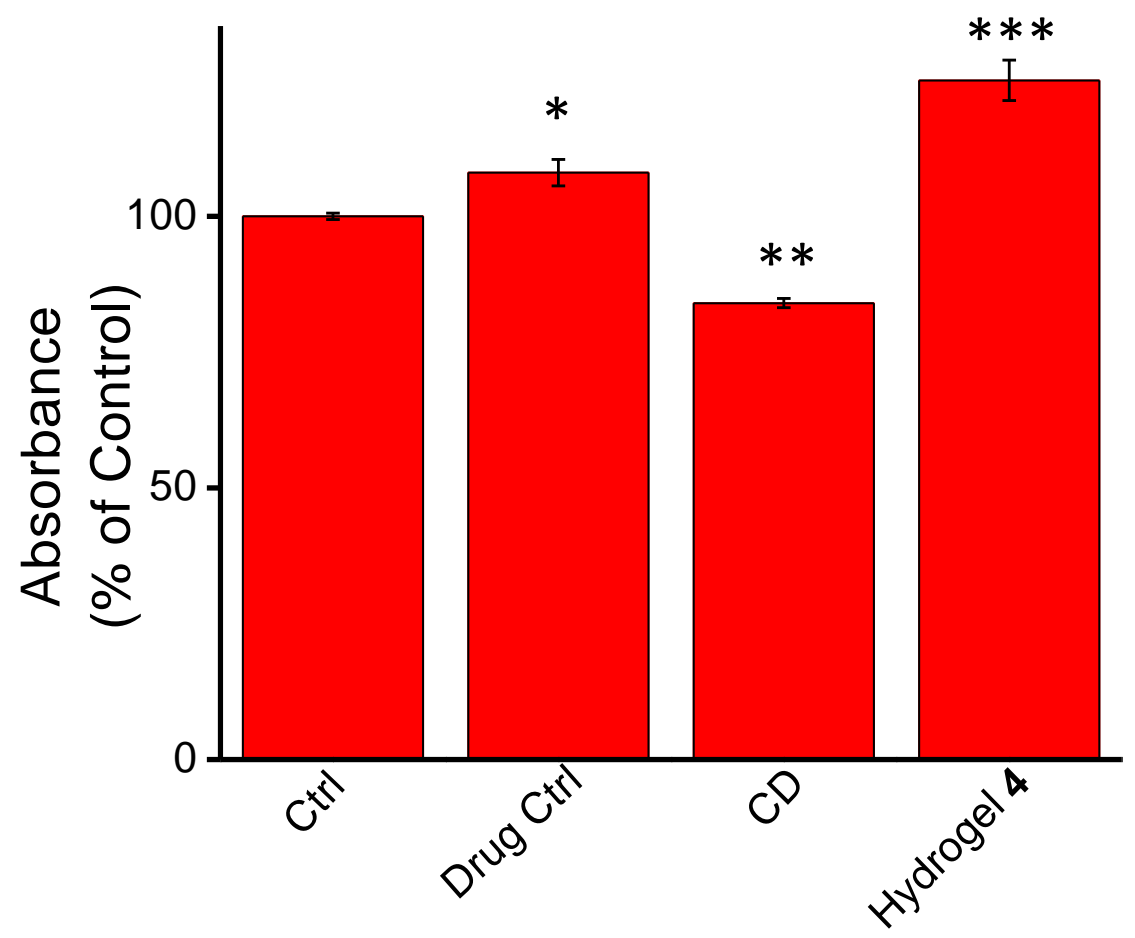

Figure S20. The total protein estimation in the wound tissue homogenate by Nanodrop spectrophotometer at $280 \mathrm{~nm}$.

\section{Statistical Analyses}

The biological data are shown as mean \pm SEM. ${ }^{*} \mathrm{p}<0.05 ;{ }^{* *} \mathrm{p}<0.01 ;{ }^{* * *} \mathrm{p}<0.001$, and ${ }^{* * * *} \mathrm{p}<$ 0.0001, as compared to the control group. The data are analyzed by one-way ANOVA (nonparamatric) followed by Newman-Keuls multiple comparison tests, using a Graph Pad Prism (GraphPad, San Diego, CA). 